\title{
ARBITRAJE Y DERECHO EUROPEO DE LA COMPETENCIA: VIEJOS PROBLEMAS Y NUEVOS DILEMAS*
}

\author{
Alfonso-Luis Calvo Caravaca \\ Catedrático de Derecho Internacional Privado \\ Universidad Carlos III de Madrid \\ Juliana Rodríguez Rodrigo \\ Ayudante Doctor de Derecho Internacional Privado \\ Universidad Carlos III de Madrid
}

Sumario: 1. Consideraciones introductorias. 2. Arbitrabilidad de las controversias concurrenciales. A) El desmoronamiento del planteamiento clásico en los ordenamientos jurídicos nacionales. B) Práctica administrativa y jurisprudencial comunitaria en la «era del Reglamento.$^{\circ}$ 17». C) Perspectiva actual (del Reglamento n. ${ }^{\circ} 17$ al Reglamento 1/2003). 3. Aplicación del Derecho de la competencia por los árbitros: Facultativa u obligatoria. 4. Cuestiones procedimentales. A) Recurso prejudicial. B) Procedimiento comunitario y procedimiento arbitral. C) Comunicación de las sentencias arbitrales a la Comisión. D) Recurso en caso de inaplicación del Derecho de la competencia. E) Retirada del beneficio de una exención por categorías. 5. Control del laudo arbitral en el exequatur.

\section{Consideraciones introductorias}

1. No es infrecuente en el arbitraje privado internacional que el órgano arbitral tenga que aplicar o, al menos, tomar en consideración el Derecho de la competencia y, en particular, el Derecho europeo de la competencia para resolver la controversia entre las partes que se han sometido a él ${ }^{1}$.

* Trabajo realizado en el marco del proyecto de investigación n. ${ }^{\circ}$ SEJ2004-03257/JURI de la Secretaría de Estado de Universidades, Investigación y Desarrollo del Ministerio de Educación y Ciencia sobre «El Derecho internacional privado en materia de sociedades y su incidencia en los procesos de integración desarrollados en Europa y América Latina».

1 Vid., ad ex. sentencia CCI n. ${ }^{\circ} 1.397 / 1966$, Clunet, 1974, pp. 879-884, con nota de Y. DeRAINS; sentencia CCI n. ${ }^{\circ} 1.675 / 1969$, Clunet, 1974, p. 895, con nota de THOMPSON; sentencia CCI n. ${ }^{\circ}$ 1.717/1972, Clunet, 1974, p. 290; sentencia CCI n. ${ }^{\circ}$ 2.811/1978, Clunet, 1979, pp. 983-989, con nota de Y. Derains; sentencia CCI n. ${ }^{\circ}$ 2.886/1977, Clunet, 1978, p. 996; sentencia CCI n. ${ }^{\circ}$ 2.930/1982, Yearbook of Commercial Arbitration, VII, 1982, p. 105; 
2. Los estudios sobre las relaciones entre el arbitraje privado internacional y el Derecho comunitario han puesto habitualmente de relieve, apoyándose en particular en los originarios arts. 181, 182 y 220 del Tratado de Roma (actuales arts. 238, 239 y 293 TCE), que la Comunidad Europea surgió con una disposición favorable a dicho medio de arreglo de controversias, aunque, durante las décadas que siguieron a su nacimiento, la Comunidad no articulase de forma adecuada esa predisposición propicia al mismo².

sentencia CCI n. ${ }^{\circ} 3.880 / 1982$, Clunet, 1983, p. 897; sentencia CCI n. ${ }^{\circ} 4.132 / 1983$, Yearbook of Commercial Arbitration, X, 1985, pp. 49-52 y Clunet, 1983, pp. 891-893, con nota de Y. DeRAINS; sentencia CCI n. ${ }^{\circ}$ 4.237/1984, Yearbook of Commercial Arbitration, X, 1985, p. 52; sentencia CCI n. ${ }^{\circ} 4.604 / 1984$, Clunet, 1985, pp. 973-981, con nota de Y. Derains; sentencia CCI n. ${ }^{\circ}$ 4.996/1985, Clunet, 1986, pp. 1.131-1.136, con nota de Y. Derains; sentencia CCI n. ${ }^{\circ}$ 5.103/1988, Clunet, 1988, pp. 1.207-1.215, con nota de AguILAR Alvarez; sentencia CCI n. ${ }^{\circ}$ 5.118/1986, Clunet, 1987, pp. 1.027-1.029, con nota de S. JARVIN; sentencia CCI n. ${ }^{\circ}$ 6.106/1991, Bul. ICC, n. ${ }^{\circ}$ 2/1994, pp. 44-50; sentencia CCI n. ${ }^{\circ}$ 6.142/1990, Clunet, 1990, pp. 1.039-1.046; sentencia CCI n. ${ }^{\circ}$ 6.149/1990, Yearbook of Commercial Arbitration, XX, 1995, pp. 41-57; sentencia CCI n. ${ }^{\circ}$ 6.283/1990, Yearbook of Commercial Arbitration, XVII, 1992, pp. 178-185; sentencia CCI n. ${ }^{\circ}$ 6.294/1991, Clunet, 1991, pp. 1.0501.054; sentencia CCI n. ${ }^{\circ} 6.320 / 1992$, Clunet, 1995, pp. 986-983, con nota de D. HASCHER y Yearbook of Commercial Arbitration, XX, 1995, pp. 63-109; sentencia CCI n. ${ }^{\circ}$ 6.475/1994, Bull. ICC, n. ${ }^{\circ} 1 / 1995$, pp. 51-53; sentencia CCI n. ${ }^{\circ}$ 6.503/1990, Clunet, 1995, pp. 1.022-1.031, con nota de Y. DeRAINS; sentencia CCI n. ${ }^{\circ} 6.614 / 1991$, Bull. ICC, n. ${ }^{\circ}$ 1/1995, pp. 53-54; sentencia CCI n. ${ }^{\circ} 6.709 / 1992$, Bul. ICC, n. ${ }^{\circ}$ 2/1994, pp. 50-51; sentencia CCI n. ${ }^{\circ} 6.719 / 1994$, Clunet, 1994, pp. 1.071-1.081; sentencia CCI n. ${ }^{\circ} 6.773 / 1992$, Bul. ICC n. $^{\circ}$ 1/1995, pp. 66-70; sentencia CCI n. ${ }^{\circ} 6.932 / 1992$, Clunet, 1994, pp. 1.065-1.071, con nota de Y. DerAINs; sentencia CCI n. ${ }^{\circ} 7.154 / 1993$, Clunet, 1994, pp. 1.059-1.064, con nota de Y. DeRAINS; sentencia CCI n. ${ }^{\circ}$ 7.181/1992, Bull. ICC, n. ${ }^{\circ}$ 1/1995, pp. 55-56 y Yearbook of Commercial Arbitration, XXI, 1996, pp. 99-112; sentencia CCI n. ${ }^{\circ}$ 7.319/1992, Bull. ICI, n. ${ }^{\circ} 2 / 1994$, pp. 56-59; sentencia CCI n. ${ }^{\circ} 7.539 / 1995$, Clunet, 1996, pp. 1.030-1.037, con nota de Y. Derains; sentencia CCI n. ${ }^{\circ} 7.673 / 1993$, Bull. ICI, n. ${ }^{\circ} 1 / 1995$, pp. 56-59; sentencia CCI n. ${ }^{\circ} 8.626 / 1996$, Clunet, 1999, pp. 1.073-1.079, con nota de J.-J. ARNÁLDEZ; sentencia CCI n. ${ }^{\circ}$ 8.423/1998, Clunet, 4, 2002, pp. 1.079-1.085, con nota de J.-J. ARNÁLDEZ.

2 P. Bonassies, «Arbitrage et droit communautaire», en L'Europe et le droit, Mélanges en hommage à J. Boulois, Paris, 1991, pp. 21 ss.; J.-J. BURST, «L'arbitrage dans ses rapports avec les Communautés européennes», Rev. arb., 1979, pp. 105 ss.; L. GofFIN, «L'arbitrage et le droit européen», Rev.int.dr.comp., 67, 1990, pp. 315-338; P.L. HETSCH, «L'arbitrage en droit communautaire», Bull. CIA, CCI, vol. 6, n. ${ }^{\circ}$ 2, nov. 1995, pp. 46-58; L. IDOT, «Arbitrage et droit communautaire», Rev.dr.aff.int., 1996, pp. 561-591; R. KovAR, «La participation de la Communauté aux conventions internationales», AFDI, 1975, pp. 903 ss.; A. MC Clellan, «Le rôle de l'arbitrage commercial et le droit communautaire dans la perspective de 1992», Revue de droit international et de droit comparé, 67, 1990, pp. 301-314; X. DE Mello, «Arbitrage et droit communautaire», Rev. arb., 1982, pp. 349-403; J. RoBERT, «De la place de l'arbitrage dans le jeu des Traités instituant les communautés européennes», Rev. arb., 1964, pp. 111 ss. y Rev. arb., 1965, pp. 3 ss.; ID., «Domaine ouvert à l'arbitrage dans le cadre du droit communautaire», Rev. arb., 1966, pp. 23 ss.; C.M. SCHMITTHOFF, «Arbitration and EEC Law», C.M.L.Rev., 24, 1987, pp. 143-157. Recientemen- 
3. Resulta difícil no compartir las anteriores afirmaciones. Pero si, en vez de examinar las relaciones entre el arbitraje y el Derecho comunitario en general, se exploran las relaciones entre el arbitraje y el Derecho europeo de la competencia, la verdad es más compleja, más sutil, más interesante.

4. Por lo pronto, cabe distinguir dos supuestos. Según el primero de ellos, un árbitro puede verse en la tesitura de tener que aplicar Derecho comunitario - en especial, sus normas sobre libre competencia (arts. 81 y 82 TCE y el Derecho derivado) - en el curso de un procedimiento arbitral entre dos empresas. Conforme al segundo supuesto, menos frecuente que el anterior, se puede pretender que una institución comunitaria actúe como árbitro para dirimir una determinada diferencia entre las partes de un litigio o puede ocurrir que sea la propia Comunidad la que intervenga como parte en un procedimiento arbitral ${ }^{3}$. En esta exposición, únicamente nos ocuparemos del primero de ambos supuestos, que es el más habitual.

5. El estudio de la aplicación de las normas comunitarias de competencia por parte de los órganos arbitrales pasa por considerar, sucesivamente, el problema de la arbitrabilidad de las cuestiones de Derecho de la competencia (= si los árbitros poseen competencia para ello), el carácter imperativo o facultativo de dicha aplicación (= si son libres para aplicarlo o, por el contrario, están obligados a ello), las cuestiones procedimentales $(=$ si poseen los mismos medios que las autoridades estatales encargadas en los Estados miembros de la aplicación de las normas de Derecho antitrust) y, por último, el control del laudo arbitral en el exequatur (= si una eventual inaplicación del Derecho de la competencia acarrea la ineficacia extraterritorial de la sentencia arbitral).

\section{Arbitrabilidad de las controversias concurrenciales}

6. Conviene, pues, que expliquemos, en primer lugar, qué se entiende por arbitrabilidad.

Técnicamente, desde un punto de vista subjetivo, la arbitrabilidad no es otra cosa que el derecho de las partes de someter una controver-

te, ad ex., M. GómEz JENE, «Internationale Schiedsgerichtsbarkeit und Binnenmarkt», IPRax, 2/2005, pp. 84-93.

3 Ad ex., STJCE de 17 de marzo de 2005, Comisión/AMI Semiconductor Belgium BVBA y otros, C-294/02: Cláusula compromisoria - Designación del Tribunal de Primera Instancia. 
sia a un órgano arbitral (= la arbitrabilidad como un derecho subjetivo de los sujetos jurídicos) $)^{4}$ o, si se prefiere, desde un punto de vista objetivo, la posibilidad de plantear, para su resolución, un asunto jurídico a un tercero imparcial libremente designado por las partes en vez de a un órgano judicial establecido por el Estado (= la arbitrabilidad como facultad de un tribunal arbitral para conocer y resolver una diferencia $)^{5}$. Se trata, en todo caso, del anverso y reverso de un mismo fenómeno jurídico: la atribución con plena efectividad del arreglo de diferencias a una instancia vinculante para las partes y alternativa a la administración estatal de justicia.

\section{A) El desmoronamiento del planteamiento clásico en los ordenamientos jurídicos nacionales}

7. El estudio del Derecho comparado pone de relieve que, de ordinario, el arbitraje sólo es posible si se trata de cuestiones o litigios de carácter patrimonial (caractère patrimonial du litige, claims of economic or financial interest), en los que hay libre disponibilidad de los derechos (libre disponibilité des droits, freely disposable claims) o de asuntos que no están regidos por normas de orden público (a mandatory statutory provision) o que no son competencia exclusiva de las autoridades estatales (competence exclusive des autorités étatiques) ${ }^{6}$. Cualquiera de estos criterios es lo suficientemente amplio para necesitar que los respectivos tribunales nacionales tengan que concretar, caso por caso, de qué tipo de diferencias se debe tratar para que sean arbitrables.

8. Ahora bien, peor, incluso, que la insatisfacción conceptual o inseguridad jurídica que pueda generar cualquiera de las tres fórmulas mencionadas, es el hecho, también demostrable por el Derecho comparado, de que subsisten grandes diferencias entre los ordenamientos jurídicos tanto desde la perspectiva del Derecho material (= si una concreta cuestión es arbitrable o no) como desde la perspectiva del Derecho

${ }^{4}$ En este sentido, ad ex., J.D.M. LEw/L.A. Mistelis/S.M. KRÖLL, Comparative Internacional Comercial Arbitration, The Hague, 2003, p. 187.

$5 \mathrm{~W}$. Abdelgawad, Arbitrage et droit de la concurrence. Contribution à l'étude des rapports entre ordre spontané et ordre organisé, Paris, 2001, p. 26; A. BUCHER, Le nouvel arbitrage international en Suisse, Bâle, 1988, p. 37; B. HANotiau, L'arbitrabilité, Rec.Cours, 2002, t. 296, pp. 40 y 42-43; J.-B. RACINE, L'arbitrage commercial international et l'ordre public, Paris, 1999, p. 25.

6 Vid., ad ex., W. ABDElGawAD, Arbitrage et droit de la concurrence..., pp. 101-114 y 119-123; B. HANOTIAU, L'arbitrabilité, pp. 107-115; J.-B. RACINE, L'arbitrage commercial international..., pp. 27-149. 
conflictual (= la determinación de la ley aplicable a la cuestión de la arbitrabilidad objetiva) ${ }^{7}$.

9. Por otra parte, el problema de la arbitrabilidad del litigio — como ha subrayado, entre otros, B. HANOTIAU- puede plantearse en cuatro distintos momentos procesales: Ante el tribunal arbitral al que se pretende someter la contienda entre las partes, ante un tribunal estatal al que se le pide que resuelva si la oposición de la parte demandada basada en la no arbitrabilidad del litigio se ajusta a Derecho, ante el órgano judicial nacional al que se le solicita la anulación de un laudo arbitral dictado en dicho asunto, carente de arbitrabilidad según el ordenamiento competente declarado aplicable por dicho tribunal estatal, o, finalmente, ante el tribunal estatal que, bien a instancia de parte o bien de oficio, debe verificar si un laudo arbitral extranjero reúne los presupuestos necesarios para obtener su reconocimiento y ejecución ${ }^{8}$.

10. Se consideró generalmente que los tribunales arbitrales no podían pronunciarse sobre la ilicitud de un comportamiento respecto del

${ }^{7}$ La determinación de la ley aplicable a la arbitrabilidad objetiva suscita dos cuestiones: quién puede plantearla (si sólo la parte o, ante el silencio de ésta, puede suscitarse por el árbitro de oficio) y cuál es el ordenamiento jurídico que la rige. Esta última cuestión puede depender de que se plantee ante el tribunal arbitral o ante un tribunal estatal al que se le ha sometido esta cuestión, bien de modo concurrente o en el marco de una acción de anulación del laudo arbitral o de obtención del exequatur. Se acostumbra a oponer la ley rectora del convenio arbitral a la ley de la sede del arbitraje o, incluso, a leyes de policía extranjeras, en particular del lugar de ejecución de la sentencia arbitral. Sobre el Derecho aplicable a la arbitrabilidad objetiva, vid., ad ex., B. HANOTIAU, L'arbitrabilité, pp. 62-93; J.-B. RACINE, L'arbitrage commercial international..., pp. 151-178; N. SPIEGEL, Kartellprivatrecht in der internationalen Handelsschiedsgerichtsbarkeit, Baden-Baden, 2002, pp. 69-145.

Con motivo de la pretendida nulidad de un contrato de licencia de marcas, la sentencia CCI n. ${ }^{\circ}$ 4.604/1984, Clunet, 1985, pp. 973-981, con nota de Y. DeRAINS, reveló un caso de false conflict. Se trataba de un tribunal arbitral con sede en Suiza, al que el demandado invocó que la diferencia era inarbitrable en virtud del Derecho italiano, tanto si se tomaba en consideración el art. 85 (actual art. 81) del Tratado de Roma como si los que se apreciaban eran los arts. 1.379 y 2.596 del Código Civil italiano. El tribunal no sólo consideró que el litigio era arbitrable conforme al Derecho de la sede del tribunal arbitral, sino que, además, advirtió que, a diferencia de lo sostenido por una de las partes, el Derecho italiano no se oponía a la solución por vía arbitral de aquella controversia. Este último ordenamiento jurídico, en dicho caso, no tenía más título de aplicación que el de ser una ley de policía extranjera y, en particular, la ley del probable lugar de ejecución de una eventual sentencia de condena.

8 AA.VV., Competition and Arbitration Law, Institut de la CCI, Paris, 1992; B. HanOTIAU, L'arbitrabilité, p. 44; G. VAN HECKE, «Arbitrage et restrictions de la concurrence», Rev. arb., 1973, pp. 143-153; ID., «Arbitrage et règles de concurrence», Rev. arb., 1978, pp. 191-195. 
Derecho de la competencia; porque — se señalaba - estas normas tienen el carácter de normas imperativas o de orden público tanto en la UE como en los Estados miembros ${ }^{9}$. «El Derecho de la competencia — se ha señalado- es una disciplina híbrida que toma prestadas sus características del Derecho civil, del Derecho penal y del Derecho administrativo y que, a menudo, recurre [...] a una autoridad especializada para sancionar los comportamientos anticompetitivos. El fin del Derecho de la competencia es preservar la competencia en una economía de mercado. Es por lo que, en Derecho de la competencia, el orden público tiene por función limitar la libertad de los agentes económicos con objeto de mantener una competencia sana y efectiva» ${ }^{10}$.

Incluso en los Estados Unidos, la jurisprudencia se inclinó por la no arbitrabilidad de las acciones basada en el Derecho antitrust, apoyándose en el efecto de los comportamientos colusorios sobre los terceros y sobre la economía en su conjunto, la complejidad de este tipo de litigios o una mejor posibilidad de protección de la parte más débil o de reunir en un proceso los elementos de prueba necesarios para acreditar este tipo de infracciones ${ }^{11}$. Según un célebre dictum del Tribunal de apelación del segundo circuito en American Safety Equipment Corp. v. McGuire \& Co. (1968), se argumentaba que: "Una demanda en materia de leyes antitrust no es únicamente un asunto privado. La Sherman Act está instaurada para promover el interés nacional en una economía competitiva; de tal manera que la parte que invoca sus derechos en función de la Act es equiparada al Attorney general que protege el interés público. Las violaciones del Derecho antitrust pueden afectar a centenas de miles, quizás millones de personas e infligir un asombroso daño económico. No pensamos que haya estado en las intenciones del Congreso que tales demandas sean resueltas además únicamente ante los tribunales» ${ }^{12}$.

Se trataría, en definitiva, de una cuestión de arbitrabilidad de la diferencia. Un laudo arbitral no tendría, por consiguiente, ningún valor legal y no podría ser ejecutado.

9 W. Abdelgawad, Arbitrage et droit de la concurrence.., pp. 16-17 y 32-45; B. GoldMAN/A. Lyon-CAen/L. Vogel, Droit commercial européen, 5. ${ }^{\text {a }}$ ed., Paris, 1994, p. 612; X. DE MELLO, «Arbitrage et ordre public national découlant des règles de la concurrence», Rev. arb., 1979, pp. 101 ss.; J.-H. MOITRY, «Arbitrage international et droit de la concurrence: vers un ordre public de la lex mercatoria?», Rev. arb., 1989, pp. 3-36; A. RigozzI, «Arbitrage, ordre public et droit communautaire de la concurrence», Bull. ASA, 1999, pp. 455-487.

10 J.-B. RACINE, L'arbitrage commercial international..., p. 98.

11 American Safety v. McGuire, 391 F.2d 821 (1968).

12 American Safety v. McGuire, 391 F.2d 821, 826 (1968). Vid., ad ex., W. AbdelgaWAD, Arbitrage et droit de la concurrence..., pp. 47-55 y 143-169. 
11. Las partes, sin embargo, suelen acudir a un órgano arbitral en materias — ad ex., contratos de distribución comercial- sometidas al Derecho de la competencia, ya sea con motivo de un incumplimiento contractual o para liberarse de una obligación contractual, generalmente en relaciones verticales (la denominada Euro-Defence o Euro-defense Einre$d e)^{13}$. Es, en este ámbito - el de las excepciones de nulidad o demandas reconvencionales de nulidad (ad ex., sentencia CCI n. ${ }^{\circ}$ 2.811/1978, Clunet, 1979, pp. 983-989, con nota de Y. DeRAINS)—, cuando un árbitro, a título incidental, podría verse obligado a tener en cuenta el Derecho comunitario de la competencia ${ }^{14}$.

13 Vid. J.R. Allison, «Arbitration Agreements and Antitrust Claims: The Need for Enhanced Accomodation of Conflicting Public Policies», North Carolina Law Review, 64, 1986, pp. 219-276, concr. pp. 239 y 258; D.I. BAKER/M.R. STABILE, «Arbitration and Antitrust Claims: Opportunities and Hazards for Corporate Counsel», Bus.Lawyer, 48, 1993, pp. 395-436, concr. p. 414; J. BEECHEY, «Arbitrability of Antitrust/Competition Law Issues - Common Law», Arbitration International, 12, 1996, pp. 179-189, concr. pp. 179-180; D. GIRSBERGER/U. WEBER-STECHER, «Die Einrede der Wettbewerbswidrigkeit vor schweizerischen Schiedsgerichten», en Der Einfluss des europäischen Rechts auf die Schweiz, Festschrift zum 60. Geburtstag von Roger Zäch, Zürich, 1999, p. 683; M.R. LEE, «Antitrust and Commercial Arbitration: An Economic Analysis», St. John's Law Review, 62, 1987, pp. 1-44, concr. p. 24; R.B. von MEHREN, «From Vynior's Case to Mitsubishi: The Future of Arbitration and Public Law», Brooklyn Journal of International Law, 12, 1986, pp. 583-628, concr. p. 617; N. SPIEGEL, Kartellprivatrecht..., p. 202.

En litigios de naturaleza extracontractual, las partes no suelen acudir al arbitraje; es lo normal que las demandas extracontractuales se planteen ante órganos jurisdiccionales (vid. L. IDOT, «Arbitration and the Reform of Regulation 17/62», en C.-D. EHLERMANN/ I. Atanasiu (eds.), European Competition Law Annual: 2001, Effective Private Enforcement of EC Antitrust Law, Oxford, 2003, pp. 309-310). En todo caso, se considera que el Derecho de la competencia desleal puede interpretarse como una cuestión particular de responsabilidad civil y es, por consiguiente, susceptible de ser resuelto mediante el recurso al arbitraje. Vid., ad ex, en este sentido, L. IDOT, «Rapport introductif», en Institute of International Business Law and Practice, Competition and Arbitration Law, Paris, 1993, pp. 11-38, concr. p. 13; J.-B. RACINE, L'arbitrage commercial international..., pp. 55 y 98-99; CL. REYMOND, "Conflits de lois en matière de responsabilité délictuelle devant l'arbitre international», TCFDIP, 1988-89, pp. 97 ss., concr. pp. 101-102.

${ }^{14}$ S. BASTIANON, «L'arbitrabilità delle controversie antitrust tra diritto nazionale e diritto comunitario», Il Foro italiano, 124, 11, 1999, IV, 471-483; C. BAUDENBACHER/ A.K. SCHNYDER, Die Bedeutung des EG-Kartellrechts für Schweizer Schiedsgerichte, Basel, 1996; H.G. Gharavi, «The Proper Scope of Arbitration in European Community Competition Law», The Tulane European and Civil Law Forum, 11, Winter 1996, pp. 185205; B. Goldman, «L'arbitrage international et le droit de la concurrence», Bull. Assoc. suisse d'arbitrage, 1989, pp. 260 ss.; D. HAHN, L'arbitrage commercial international en Suisse face aux règles de concurrence de la CEE, Genève, 1983; C. KAPLAN, «L'arbitrabilité des litiges commerciaux en matière de droit de la concurrence», DPCI, 1988, n. ${ }^{\circ} 3$, pp. 403-426; R. KovAR, «Droit communautaire de la concurrence et arbitrage», en Le droit des relations économiques internationales. Etudes offertes à Berthold Goldman, Paris, 
12. Históricamente, la evolución de la arbitrabilidad ha sido favorable, a lo largo del siglo Xx, al arbitraje (el denominado favor arbitrandum $)^{15}$. Hasta mediados de los años 80 , sin embargo, la tesis de la no arbitrabilidad de las diferencias relativas a cuestiones de competencia no se mostró en franca retirada ${ }^{16}$.

Cabe recordar, en este sentido, que ya el Prof. B. Goldman consideró que los litigios en los que se tenga que aplicar el Derecho comunitario de la competencia deberían poder ser sometidos a arbitraje internacional, sin que deba distinguirse entre la demanda que tiene por objeto la nulidad de un contrato por incompatibilidad con las reglas de competencia y la excepción o defensa contra la ejecución de un contrato basada en la misma, distinción «no justificada por ninguna razón lógica pues, en un caso como en otro, el árbitro está llamado a "inmiscuirse" en el orden público económico de la legislación aplicable» ${ }^{17}$.

13. Efectivamente, dejando a un lado el tema — tan complejo- de las concentraciones de empresas, que, en la práctica administrativa y judicial, goza de una cierta autonomía dentro del Derecho de la competencia, la interpretación defendida por el Prof. B. GoldMAn se impuso tanto en las legislaciones estatales como en la práctica arbitral internacional:

14. a) En algunos ordenamientos jurídicos (Derecho suizo y alemán), se admitió la arbitrabilidad de las diferencias que conciernen al Derecho de la competencia, siempre que las partes se reserven el derecho a recurrir al juez estatal, una vez que haya surgido la controversia (recurso opcional al juez $)^{18}$.

1982, pp. 109-124; P.J. SLOT, «The Enforcement of EC Competition Law in Arbitral Proceedings», Leg.Iss.Eur.Integr., 1996, 1, pp. 101-113; P. ZoBEL, «Art. 81 EGV im Schiedsgerichtsverfahren», Wirtschaftsrechtliche Blätter, 15, Juli 2001, pp. 300-307.

15 Vid., ad ex., B. Hanotiau, «L'arbitrabilité», p. 40; D. HASCHER, «Les conditions d'arbitrabilité et la jurisprudence - Rapport introductif», en Institute of International Business Law and Practice, Competition and Arbitration Law, Paris, 1993, pp. 153-165.

16 Vid., ad ex., B. HANOTIAU, «L'arbitrabilité et la favor arbitrandum: un réexamen», Clunet, 1994, pp. 899-966, concr. pp. 940-951; ID., «L'arbitrage et le droit européen de la concurrence», en R. BRINER/Y. DERAINS [et al.], L'arbitrage et le Droit Européen, Bruylant, Bruxelles, 1997, pp. 31-64; D.G. LANGE/S. WIESSNER, «Die Schiedsfähigkeit internationaler Antitrust-Streitigkeiten», RIW, 1995, pp. 757-765; M.R. LEE, «Antitrust and Commercial Arbitration: An Economic Analysis», St. John's Law Review, 62, 1987, pp. 1-44.

17 B. Goldman/A. Lyon-Caen/L. Vogel, Droit commercial européen, 5. a ed., Paris, 1994, p. 612.

18 W. Abdelgawad, Arbitrage et droit de la concurrence..., pp. 177-181 y 186-187; M. DE BoISSÉSON, Le droit français de l'arbitrage interne et international, Paris, 1990, p. 509; 
15. b) La Ley federal suiza sobre cárteles de 20 de diciembre de 1985 estableció de manera expresa la arbitrabilidad de las materias de Derecho de la competencia, al igual que hizo la nueva Ley federal suiza de cárteles de 6 de octubre de $1995^{19}$. La jurisprudencia suiza ya había confirmado la arbitrabilidad de los litigios relativos al Derecho de la competencia en el asunto Societé G. v. Societé $V^{20}$.

16. c) El Tribunal Supremo de los Estados Unidos se inclinó en favor de la arbitrabilidad de las cuestiones de Derecho de la competencia, del no reconocimiento del laudo que ignore esta cuestión y de la aplicabilidad de oficio del Derecho de la competencia, incluso si es un Derecho extranjero el rector del contrato, en Mitsubishi Motors v. Soler Chrysler-Plymouth ${ }^{21}$, jurisprudencia que fue extendida a los arbitrajes

W. KüHN, «Arbitrability of Antitrust Disputes in the Federal Republic of Germany», Arbitration International, 1987, pp. 226-239; N. SPIEGEL, Kartellprivatrecht..., pp. 60-62 y 63-67.

19 Vid. M. BLESSING, Introduction to Arbitration - Swiss and International Perspectives, Basel, 1999, p. 259.

20 Sentencia del Tribunal Federal suizo de 28 abril 1992, G.S.A./V.S.p.A., Rev. arb., 1993, p. 124, con nota de L. IDOT.

${ }^{21}$ United States Supreme Court, 2 July 1985, Yearbook of Commercial Arbitration, 1986, p. 555; también en Int'l Legal Materials, 24, 1985, p. 1064. Vid. W. ABdELGawad, Arbitrage et droit de la concurrence..., pp. 87-96; P. BERNARDINI, «Stati Uniti: arbitrabilità di controversie in materia di legislazione antitrust», Rassegna dell'arbitrato, 1985, pp. 109-121; TH. E. CARBoneaU, «Mitsubishi: The Folly of Quixotic-Internationalism», Arbitration International, 1986, pp. 116-140; ID., «The Exuberant Pathway to Quixotic Internationalism: Assessing the Folly of Mitsubishi», Vanderbilt Journal of Transnational Law, 19, 1986, pp. 265-298; Sh.L. Cloud, «Mitsubishi and the Arbitrability of Antitrust Claims: Did the Supreme Court Throw the Baby Out with the Bathwater?», Law and Policy in International Business, 18, 1986, pp. 341-369; C. Q. Corinne Troung, Les différends lies à la rupture des contrats internationaux de distribution dans les sentences arbitrales CCI, Litec, Paris, 2002, p. 113; R.M. DonALDSON, «Mitsubishi and Antitrust Arbitration - It's All the Japanese You Need to Know», Brigham Young University Law Review, 1986, pp. 219-232; L.M. FERRI, «International Arbitration - Commerce - Arbitrability of Antitrust Claims Arising from International Commercial Disputes Recognized under Federal Arbitration Act - Mitsubishi Motors Corp. v. Soler Chrysler-Plymouth, Inc., 105 S.Ct. 3346 (1986)», Seton Hall L. Rev., 17, 1987, pp. 448-473; R.E.M. Goodman, «Arbitrability and Antitrust: Mitsubishi Motors Corp. v. Soler Chrysler-Plymouth», Columbia Journal of Transnational Law, 23, 1984-1985, pp. 655-678; J. GRIFFIN, «U.S. Supreme Court Encourages Extraterritorial Application of U.S. Antitrust Laws», International Business Lawyer, 1993, pp. 389-393; A.F. LowENFELD, «The Mitsubishi Case: Another View», Arbitration International, 1986, pp. 178-190; J.P. MCGRATH, «Son of Mitsubishi - Arbitration of Domestic Antitrust Disputes», Brooklyn Journal of International Law, 12, 1986, pp. 693-702; R.B. VON MEHREN, «From Vynior's Case to Mitsubishi: The Future of Arbitration and Public Law», Brooklyn Journal of International Law, 12, 1986, pp. 583-628; L. NEWTON, «Arbitration and Antitrust: A Leg Up for International Arbitration [Mitsubishi Motors Corp. v. Soler Chrysler-Plymouth, Inc. 105 S.Ct. 3346 (1985)]», Washburn L.J., 25, 1985-1986, pp. 536-551; PH. O’NeILL, «Recent 
internos por una decisión del Tribunal federal de distrito, Distrito de Puerto Rico, de 17 de noviembre de $1989^{22}$.

17. Parece conveniente recordar el supuesto que originó la sentencia del Tribunal Supremo de Estados Unidos de 2 julio 1985 en el caso Mitsubishi Motors v. Soler Chrysler-Plymouth Mitsubishi. El caso fue el siguiente: La sociedad suiza Chrysler Internacional S.A. (CISA) firmó un acuerdo de distribución con la sociedad puertorriqueña Soler Chrysler Plymout Inc. (Soler) — distribuidor en Puerto Rico-, en virtud del cual Soler debía vender un número determinado de coches Mitsubishi al año en un área concreta (el territorio de Puerto Rico). Esos coches serían fabricados por Mitsubishi Motors Corporation, sociedad japonesa constituida a través de una joint venture entre CISA y Mitsubishi Heavy Industries. En cumplimiento del acuerdo de distribución, CISA, Soler y Mitsubishi firmaron ese mismo día un contrato que disponía la venta directa de los productos de Mitsubishi a Soler. En este contrato, había una cláusula compromisoria, en virtud de la cual las partes acordaron que,

Developments in International Commercial Arbitration: an American Perspective», Arbitration, 1987, pp. 177-186; K.L. PALMER, «Mitsubishi: The Erosion of the New York Convention and International Arbitration», Wis. Int'l L.J., 1984, pp. 151-182; J. PARNASS, «International Arbitration and the Comity of Error: Mitsubishi Motors Corp. v. Soler ChryslerPlymouth, Inc.», Conn. L. Rev., 19, 1986-1987, pp. 435-466; F.R. PETTI, «Enforcement of Agreements to Arbitrate Federal Antitrust Claims in the International Arena: Mitsubishi Motors v. Soler Chrysler-Plymouth», Ariz. J. Int'l \& Comp. L., 1986, pp. 213-226; J.A. PIETROWSKI, «Enforcing International Commercial Arbitration Agreements - Post-Mitsubishi Motors Corp. v. Soler Chrysler-Plymouth, Inc.», Am. U. L. Rev., 36, 1986-1987, 37, pp. 57-92; E.A. POSNER, «Arbitration and the Harmonization of International Commercial Law: A Defense of Mitsubishi», Vanderbilt Journal of International Law, 39, 1988-1989, pp. 647-670; M.A. RENOLD, «Arbitrage international et droit antitrust: l'arrêt Mitsubishi v. Soler de la Cour suprême des Etats-Unis», Zeitschrift für Schweizerisches Recht, 1986, pp. 545-552; J. ROBERT, «Une date dans l'extension de l'arbitrage international: l'arrêt Mitsubishi contre Soler», Rev. arb., 1986, pp. 173-189; R.A. RотH, «Application of the Convention on the Recognition and Enforcement of Foreign Arbitral Awards: Mitsubishi Motors Corp. v. Soler Chrysler-Plymouth, Inc.», Fordham Int. L.J., 8, 1984-1985, pp. 194-225; L. SoPATA, «Mitsubishi Motors Corp. v. Soler Chrysler-Plymouth, Inc.: International Arbitration and Antitrust Claims», Nw. J. Int'l L. \& Bus., 7, 1985-1986, pp. 595-617; M.R. VoORHEES, «International Commercial Arbitration and the Arbitrability of Antitrust Claims: Mitsubishi Motors Corp. v. Soler Chrysler-Plymouth», N. Ky. L. Rev., 14, 1987, pp. 65-90; L.L. WALSH, «Arbitration in International Commercial Transactions: Mitsubischi Motors Corp. v. Soler Chrysler-Plymouth, Inc. and its aftermath», Syracuse Journal of International Law and Commerce, vol. 13, n. ${ }^{\circ} 1,1986$, pp. 200-216; M.D. WILKINSON, «Judicial Review of Foreing Arbitral Awards on Antitrust Matters After Mitsubishi Motors», Columbia Journal of Transnational Law, 26, 1988, pp. 407-427.

22 Yearbook of Commercial Arbitration, 1991, p. 637. Vid. W. ABDELGAWAD, Arbitrage et droit de la concurrence..., pp. 125-126; J.P. MCGRATH, «Son of Mitsubishi - Arbitration of Domestic Antitrust Disputes», Brooklyn Journal of International Law, 12, 1986, pp. 693-702. 
de surgir controversias, acudirían a la Asociación Japonesa de Arbitraje Comercial, y una cláusula relativa a la ley aplicable que elegía, como rector del contrato, al Derecho suizo. Después de un período de tiempo de éxito, Soler no pudo mantener el volumen de ventas y solicitó a CISA y Mitsubishi que le permitieran vender los coches fuera del área predeterminada — en concreto, a Estados Unidos e Hispanoamérica-, petición que fue denegada por CISA.

Llegado el momento de la disputa, Soler acudió a la Corte de Puerto Rico para presentar una demanda. Se originó así un procedimiento judicial, en el transcurso del cual Soler alegó la infracción por CISA y Mitsubishi de la Sherman Act y otras normas de competencia. Dichas empresas eran responsables - según Soler- de prácticas restrictivas de la competencia, como la división del mercado o la prohibición de reventa de vehículos a Estados Unidos y países hispanoamericanos.

18. El asunto llegó a la Suprema Corte de Estados Unidos, la cual afirmó lo siguiente:

«La importancia de la indemnización privada de daños... no impone la conclusión de que no debería ser buscada fuera de un tribunal americano. A pesar de su importante función incidental de policía, la acción por el triple de los daños concedida a las partes por la Sección 4 de la Clayton Act... y perseguida por Soler... busca, en primer lugar, permitir que un competidor perjudicado gane una compensación por el daño.

La Sección 4... es, en esencia, una disposición para poner remedio al daño. Confiere el triple de los daños a cualquier persona que sea perjudicada en su negocio o propiedad por razón de cualquier comportamiento prohibido por las leyes antitrust. Por supuesto, el triple de los daños también juega un papel importante en la penalización de malhechores y en la disuasión de la maldad, como también frecuentemente hemos observado... Sin embargo, es verdad que la disposición acerca del triple de los daños, disponible sólo para las partes perjudicadas, y que se mide como un múltiplo de los daños probados, está prevista en primer lugar como un remedio.

No hay razón para dar por sentado en el principio de la disputa que el arbitraje internacional no será un mecanismo adecuado. Es seguro que el tribunal arbitral internacional no deberá aplicar, en un primer momento, las normas legales de un Estado particular; por tanto, no está obligado a justificar sus decisiones. De todos modos, el tribunal está obligado a observar las intenciones de las partes. Donde las partes han acordado que el tribunal arbitral decida en relación con un conjunto definido de demandas, entre las cuales se incluye, como en estos casos, aquéllas que provienen de la aplicación del Derecho americano de antitrust, el tribunal debería estar vinculado a decidir la disputa de acuerdo con el Derecho nacional alegado en la demanda. Con tal que el futuro litigante efectivamente pueda justificar el fundamento le- 
gal de su acción ante el foro arbitral, las normas continuarán sirviendo a las dos funciones de remedio y de prevención» ${ }^{23}$.

19. Deben, pues, formularse varias consideraciones en relación con este célebre dictum:

Primera: El Tribunal Supremo de los Estados Unidos reconoció expresamente que para resolver una cuestión de Derecho privado (unas indemnizaciones por daños), puede resultar necesario que un tribunal arbitral aplique o, al menos, tome en consideración unas normas - las del Derecho antitrust - que tienen las características del Derecho público o, al menos, del denominado Derecho económico (= los tribunales arbitrales están obligados a aplicar el Derecho antitrust ${ }^{24}$. Es más, dado que el contrato de suministro preveía la aplicación del Derecho suizo, es evidente que la «doctrina Mitsubishi» significa que los tribunales arbitrales tienen la obligación de aplicar de oficio el Derecho antitrust, aunque el contrato del que surja la diferencia entre las partes esté regido por un ordenamiento jurídico extranjero.

Segunda: En otras partes de esta sentencia, el Tribunal Supremo de los Estados Unidos empleó dos argumentos complementarios del principal. Por un lado, razones de cortesía internacional (international comity) frente a tribunales extranjeros, así como razones de previsibilidad o seguridad jurídica de los medios de arreglo de diferencias en el comercio internacional requerían que se ejecutase el acuerdo de las partes ${ }^{25}$, aun sabiendo que, de tratarse de un litigio doméstico y no de un litigio internacional, en el futuro la respuesta no sería la misma. Por otro, la idea de que, en principio, un litigio es arbitrable, salvo que el Congreso de los Estados Unidos disponga lo contrario en una ley especial $^{26}$. Este obviamente no era el caso de la Sherman $A c t^{27}$. La exigencia de dicha ley especial venía impuesta por un dato: La política federal era claramente favorable al arbitraje ${ }^{28}$. La adopción por los Estado Unidos del Convenio de Nueva York de 1958 no hacía sino confirmar esto.

Tercera: El Tribunal Supremo de los Estados Unidos — como se ha observado- probablemente dio por supuesto que, una vez dictado el laudo arbitral, éste sería presentado para su reconocimiento y, en su

23473 U.S. 614.

24 Se ha visto en este hecho una muestra de la privatización del Derecho de la competencia impulsada por el pensamiento neoliberal. Vid. W. ABDELGawad, Arbitrage et droit de la concurrence..., pp. 117-119.

25473 U.S. 628.

26473 U.S. 625.

27473 U.S. 628.

28473 U.S. 626. 
caso, eventual ejecución ante una corte estadounidense, lo que no necesariamente tenía por qué ocurrir ${ }^{29}$.

Ahora bien, en el caso de que efectivamente se presentase a reconocimiento ante los tribunales estadounidenses, éstos estarían obligados a verificar si el tribunal arbitral aplicó correctamente el Derecho antitrust norteamericano y a denegar el exequatur, por violación del orden público, si no hubiera sido así: Esta es la denominada Second Look Doctrine ${ }^{30}$.

Cuarta: Con este fallo se puso fin a la doctrina de American Safety v. McGuire, 391 F.2d 821 (1968). Sin duda ayudó el hecho de que, como se ha observado por algunos autores, la jurisprudencia estadounidense había mostrado, en alguna ocasión, una tendencia a interpretar restrictivamente la inarbitrabilidad de un litigio, precisamente a propósito de cuestiones colusorias ${ }^{31}$.

20. d) Incluso en Francia, país que es sede de numerosos procedimientos arbitrales, la jurisprudencia acabó admitiendo ampliamente la arbitrabilidad de los litigios relativos al Derecho europeo de la competen$\mathrm{cia}^{32}$, tras los casos Almira Films ${ }^{33}$, Ganz $^{34}$, Labinal $^{35}$, Velero $^{36}$ y Aplix ${ }^{37}$.

21. e) Por su parte, la jurisprudencia italiana también apostó por la arbitrabilidad de la controversia, cuando ésta sea relativa al Derecho de la competencia ${ }^{38}$.

29473 U.S. 638. Vid. S. JARVIN, «Mitsubishi ICC comment» Journal of International Arbitration, 4, 1, 1987, p. 87; J. WERnER, «A Swiss Comment on Mitsubishi», Journal of International Arbitration, 3, 4, 1986, p. 81.

30 W.W. PARK, «National Law and Commercial Justice: Safeguarding Procedural Integrity in International Arbitration», Tulane Law Review, vol. 63, 1989, pp. 647 ss., concr. p. 668.

31 Vid. W. Abdelgawad, Arbitrage et droit de la concurrence..., pp. 56-59; B. Hanotiau, L'arbitrabilité, p. 122, nota 278.

${ }^{32}$ N. SPIEGEL, Kartellprivatrecht..., pp. 49-58.

33 Decisión de la Corte de Apelación de París de 16 de febrero de 1989, Almira Films, Rev. arb., 1989, p. 711, con nota de L. IDOT. Vid., CH. JARROSON, «L'arbitrage et le droit de la concurrence», Rev. arb., 1990, pp. 947-951.

${ }^{34}$ Decisión de la Corte de Apelación de París de 29 de marzo de 1991, Ganz, Rev. arb., 1991, p. 478, con nota de L. IDOT.

35 Sentencia del Tribunal de París de 19 de mayo de 1993, Labinal, Rev. arb., 1993, p. 645, con nota de Ch. JARrosson, y Clunet, 1993, p. 957, con nota de L. IDOT.

36 Sentencia del Tribunal de París de 14 de octubre de 1993, Velero, Rev. arb., 1994, p. 164 , con nota de CH. JARROSSON..

37 Decisión de la Corte de Apelación de París de 14 de octubre de 1993, Aplix/Velcro, Rev. arb., 1994, p. 164, con nota de CH. JARROSSON.

38 Decisión de la Corte de Apelación de Bolonia de 14 de octubre de 1991, Yearbook, 1993, p. 422. Vid., ad ex., N. SPIEGEL, Kartellprivatrecht..., pp. 58-60. 
21. f) Finalmente, la jurisprudencia sueca admitió que los árbitros, a la hora de dictar sus laudos, deban tener en cuenta las normas que protegen intereses públicos para, así, evitar que éstos puedan ser recurridos por contravenir los principios de orden público ${ }^{39}$.

22. En definitiva, actualmente cabe afirmar que, con carácter general, las disputas sobre Derecho de la competencia son arbitrables. No cabe extrañarse, pues, de que, en la práctica arbitral contemporánea, existan laudos arbitrales que den por supuesta o, incluso, evidente dicha arbitrabilidad ${ }^{40}$.

23. Ahora bien, una cosa es esto y otra muy distinta afirmar que cualquier litigio concurrencial es potencialmente arbitrable o tiene el mismo grado de probabilidad de acabar en un arbitraje privado internacional. Como pusieron de relieve D.I. BAKER/M.R. STABILE, cabría distinguir cuatro grupos de casos típicos ${ }^{41}$ :

1. $\left.{ }^{\circ}\right)$ Aquéllos en los que las partes instauran entre ellas una alianza especial con finalidad cooperativa y carácter permanente (partnership disputes): Contratos de distribución comercial, acuerdos de transferencia de tecnología en sentido amplio (contratos de licencia de patentes, contratos de know how) y contratos de constitución de filiales comunes (joint ventures).

2. $\left.{ }^{\circ}\right)$ Conflictos entre compradores y vendedores acerca de sus obligaciones recíprocas, especialmente en el marco de restricciones verticales, negativa de ventas o reproches de abuso de posición dominante.

3..$^{\circ}$ Disputas en el marco de relaciones, asociaciones o uniones especiales acerca de cooperación con terceros en violación de lo pactado.

4. $\left.{ }^{\circ}\right)$ Disputas entre empresas competidoras entre las que no existe ninguna relación jurídica especial.

En principio, como señalan estos autores, sólo los dos primeros grupos de casos serían adecuados para una solución de diferencias arbitral. Existe una buena razón para llegar a esta conclusión: Dado que el

39 Decisión T 4.366-02 de la Corte de Apelación del Oeste de Suecia, 29 de diciembre de 2003, Dirland Télécom SA v. Viking Télécom AB. Vid. G. BlanKe, «The Role of EC Competition Law in International Arbitration: a Playdoyer», Eur.Bus.L.Rev., vol. 16, 1, 2005, p. 173.

40 Vid. N. SPIEGEL, Kartellprivatrecht..., pp. 203-204.

${ }^{41}$ D.I. BAKer/M.R. Stabile, Arbitration and Antitrust Claims..., pp. 395-436, concr. pp. 398-399. 
arbitraje requiere el acuerdo entre las partes, es poco probable que en los dos últimos grupos de casos —en los que no existe una relación contractual entre los eventuales litigantes-, estos pacten el recurso a un procedimiento arbitral, en vez de acudir directamente a la Comisión, a las autoridades nacionales de defensa de la competencia o a los tribunales estatales ${ }^{42}$.

24. No obstante, no hay que olvidar que:

1. $\left.{ }^{\circ}\right)$ Un árbitro no puede considerarse una autoridad nacional, porque no administra justicia en nombre de un Estado ${ }^{43}$. Es ésta una cuestión de extrema importancia, que explica, en parte, la desconfianza que algunos juristas experimentan ante la posibilidad de que los árbitros puedan resolver cuestiones relacionadas con el Derecho de la competencia ${ }^{44}$. Pero es también una interrogante parcialmente también superada: La experiencia del arbitraje privado internacional pone de relieve que los árbitros han recurrido frecuentemente al Derecho de la competencia y, además, han obrado diligentemente, sin que se haya desencadenado, por ello, el desprestigio global del arbitraje temido por un sector doctrinal o ese kiss of death for international arbitration anunciado por algún autor (J. WERNER $)^{45}$.

Con todo, el hecho de que el árbitro no sea una autoridad estatal, sino un particular que administra justicia en nombre de las partes que lo han designado no es, de ninguna manera, un dato baladí, puesto que explica:

a') El problema del argumento venire contra factum proprium. A un árbitro puede resultarle escandaloso - ha observado, entre otros, N. SPIEGEL- que una empresa solicite que se declare, en favor suyo, la nulidad de un contrato, alegando que vulnera el Derecho antitrust, cuando probablemente fue ella misma la que propuso la entente que se encuentra en el origen de la denuncia y la ha realizado durante años ${ }^{46}$. En consecuencia, el árbitro puede sentirse inclinado a no aplicar el Derecho de

42 Vid., ad ex., en este sentido, N. SPIEGEL, Kartellprivatrecht..., pp. 200-203.

43 STJCE de 23 de marzo de 1982, Nordsee, C-102/81, Rec. 1982, p. 1.095, apartado 13. Vid., ad ex., W. AbDelgawAd, Arbitrage et droit de la concurrence..., p. 18.

${ }^{44}$ Sobre esta cuestión, vid., ad ex., H.G. GHARAvI, «EC Competition Law and the Proper Scope of Arbitration», Arbitration, 63, 1987, pp. 59-66, concr. pp. 65-66; N. SPIEGEL, Kartellprivatrecht..., concr. pp. 212, 233 y 265; E. STEINDORFF, «Kartellrecht und Schiedsgerichtsbarkeit», WuW, 1984, pp. 189-200, concr. pp. 190, 197 y 199; L. VOLLMER, «Verfassungsrechtliche Grenzen der Kartellschiedsgerichtsbarkeit», WuW, 1969, pp. 421-434, concr. p. 591; J. WERNER, «Application of Competition Law by Arbitrators: The Step Too Far», Journal of International Arbitration, 1995, 1, pp. 21-26, concr. pp. 24-25.

45 J. WERNER, «Application of Competition Law...», concr. p. 25.

46 Sobre esta cuestión, vid., ad ex., N. SPIEGEL, Kartellprivatrecht..., pp. 225-230. 
la competencia, basándose en viejos principios jurídicos como nemo propia turpitudinem suam, par in pari o venire contra factum proprium. Por el contrario, para un juez está claro - y debiera estarlo también para un árbitro- que la competencia es una política, que protege un interés público, no sólo intereses particulares, y que, por consiguiente, debe declararse de oficio la nulidad de un acuerdo contrario al Derecho antitrust, cualquiera que haya sido el comportamiento de las partes que hayan participado en él antes o durante el procedimiento judicial o arbitral ${ }^{47}$.

b') Las dificultades con que, a veces, tropieza la práctica de la prue$b a$. En muchos procedimientos arbitrales, se deja de aplicar el Derecho de la competencia porque no consiguen probarse los comportamientos anti$\operatorname{competitivos}^{48}$. Es cierto que esta dificultad no es privativa de los procedimientos arbitrales: Esencialmente, es la misma que tienen que afrontar los tribunales civiles estatales ${ }^{49}$. No obstante, los jueces disponen de medios coercitivos de obtención de pruebas (ad ex., la pre-trial discovery), de los que los árbitros carecen. Como ha afirmado H.G. GHARAVI, los tribunales arbitrales internacionales están pobremente equipados (poorly equipped) para la tarea de encontrar los hechos ${ }^{50}$.

c') Los impedimentos que encuentra la cooperación de las autoridades judiciales o administrativas de los Estados con los órganos arbitrales. Aunque la generalidad — no la totalidad - de la doctrina defiende una estrecha colaboración de autoridades judiciales o administrativas estatales con los órganos arbitrales, a los que se les exige que apliquen correctamente el Derecho de la competencia, es lo cierto que, hoy por hoy, dicha colaboración es escasa, supone trabajo y ninguna compensación para los tribunales u órganos administrativos estatales y, en todo caso, no es vinculante para el órgano arbitral ${ }^{51}$. Por el contrario, la conciencia de que vivimos en una economía globalizada, que los comportamientos de las empresas no se detienen en las fronteras de los Estados y que una cooperación interestatal es recíprocamente beneficiosa ha favorecido una política de cooperación internacional en materia de libre competencia, cuyos logros son, por el momento, muy desiguales ${ }^{52}$.

47 Ibidem, p. 227.

48 Ibidem, pp. 230-232, 271-272 y 282.

49 L. IDOT, «Arbitrage et droit communautaire», pp. 561 ss., concr. p. 576.

${ }^{50}$ H.G. Gharavi, «EC Competition Law and the Proper Scope of Arbitration», Arbitration, 63, 1987, pp. 59 ss., concr. p. 66.

51 Vid. N. SPIEGEL, Kartellprivatrecht..., pp. 266-269.

52 Vid., ad ex., D. BAETGE, «Competition law and perspectives for harmonisation», Uniform Law Review, 9, 3, 2004, pp. 501-510; C. CANENBLEy/M. RosentHAL, «Co-operation between antitrust authorities in - and outside the EU: what does it mean for multinational corporations? Part 1», Eur.Compet.L.Rev., 26, 2, 2005, pp. 106-114; C. CANENBley/ 
d') Las limitaciones de la eficacia de un eventual laudo futuro frente a terceros (Das Aussenseiterproblem). Como una consecuencia más del origen contractual del arbitraje, el órgano arbitral carece de facultades para obligar a participar en el procedimiento arbitral a quienes no están obligados por el acuerdo arbitral y para imponerles el cumplimiento del eventual laudo. Para dichos sujetos (terceros, outsiders), el acuerdo o compromiso arbitral, el procedimiento y el laudo arbitral no son más que res inter alios acta, que ni les beneficia ni les perjudica. La única manera de llevarles ante un tercero imparcial es recurrir a los tribunales estatales. Pero esta solución tiene serios inconvenientes: El riesgo de dos -o más - procedimientos paralelos, al menos uno de ello arbitral, sobre el mismo asunto y el posible pronunciamiento de resoluciones contradictorias. Para evitar este problema se ha sugerido la abstención de los árbitros en este tipo de asuntos y la sumisión de todas las posibles acciones a los tribunales estatales (el denominado principio de indivisibilidad) ${ }^{53}$.

2. $\left.{ }^{\circ}\right)$ Además, al menos, no parece probable que, en caso de acuerdos que supongan una concentración económica, quepa la actuación de un órgano arbitral. Hay una buena razón para esto: Tanto las legislaciones internas como el Derecho comunitario prevén un procedimiento administrativo especial y previo para la autorización de las operaciones de

M. Rosenthal, «Co-operation between antitrust authorities in - and outside the EU: what does it mean for multinational corporations? Part 2», Eur.Compet.L.Rev., 26, 3, 2005, pp. 178-187; СH. DAMro, «Multilateral competition policy and transatlantic compromise», European Foreign Affairs Review, 9, 2, Summer 2004, pp. 269-287; M. ${ }^{a}$ P. DíAZ CremADES, «Los elementos de un posible (?) Acuerdo Multilateral de Competencia. Crónica de unas negociaciones que siguen», Not.UE, n. ${ }^{\circ} 242,2005$, pp. 33-44; J. DREXL, «International competition policy after Cancún: placing a Singapore issue on the WTO development agenda», World Compet., 27, 3, 2004, pp. 419-457; ID., «WTO und Kartellrecht: zum warum und wie dieser Verbindung in Zeiten der Globalisierung», ZWeR, 2, 2, 2004, pp. 191-249; A. HeinemanN, «La nécessité d'un droit mondial de la concurrence», Rev.int.dr.écon., 18, 3, 2004, pp. 293-324; CHR.B. HüSKEN, «Die soziale Funktion des Wettbewerbs: Bedarf es eines fusionskontrollrechtlichen Regulierungssystems der WTO in Anlehnung an nationalstaatliche Regulierung?», Zeitschrift für europarechtliche Studien, 7, 4, 2004, pp. 605-624; U. ImMENGA, Internationales Wettbewerbsrecht: Unilateralismus, Bilateralismus, Multilateralismus, Halle (Saale), 2004; M. PALLEK, «L'avenir de la coopération euro-américaine dans le domaine de la concurrence», Cah.dr.eur., 40, 1-2, 2004, pp. 95-155; G. RoEbling, «The launch of the new ICN Cartel Working Group», Competition Policy Newsletter, 2004, 2, pp. 28-30; E. DE LA SERRE, «L'assistance judiciaire américaine au soutien d'une plainte en droit communautaire de la concurrence», Rev.dr.aff.int., 2005, 1, pp. 35-53; J.H. SHENEFIELD, «Coherence or confusion: the future of the global antitrust conversation», Antitrust Bull., 49, 1-2, Spring-Summer 2004, pp. 385-434; R. WeinRauch, Competition Law in the WTO: the rationale for a framework agreement, Wien, 2004.

53 Vid. D.I. BAKER/M.R. STABILE, «Arbitration and Antitrust Claims...», pp. 395-436, concr. pp. 421-422; N. SPIEGEL, Kartellprivatrecht..., pp. 273-275. 
concentración empresarial. En él, suelen debatirse todas las posibles cuestiones jurídicas que puedan interesar al Derecho de la competencia ${ }^{54}$. Otra cuestión, sin embargo, es el hecho de que la normativa comunitaria específica para las concentraciones sí pueda, eventualmente, interesar en el transcurso de un procedimiento arbitral ${ }^{55}$.

\section{B) Práctica administrativa y jurisprudencial comunitaria en la «era del Reglamento . $^{\circ} 17$ »}

25. Al margen de la evolución experimentada por las legislaciones nacionales, no cabe extrañarse de que, dada la extraordinaria importancia que tiene el arbitraje como medio de arreglo de las controversias en el comercio internacional y el enorme apogeo experimentado por el Derecho europeo de la competencia, las instituciones comunitarias tuvieran, en diversas ocasiones, estando aún vigente el Reglamento n. ${ }^{\circ}$ 17, que enfrentarse a las relaciones entre ambos:

26. a) Así, la Comisión reaccionó frente al mecanismo arbitral previsto, cuando temió que sirviese para eludir las obligaciones derivap. 99.

${ }^{54}$ Vid., ad ex., en este sentido, J.-B. RACINE, L'arbitrage commercial international...,

55 Así, ad ex., en el caso contemplado por sentencia CCI n. ${ }^{\circ} 8.423 / 1998$, Clunet, 4, 2002, pp. 1.079-1.085, con nota de J.-J. ARNÁLDEZ, los árbitros se encontraron con los siguientes hechos: Dos sociedades portuguesas reprochaban a una sociedad francesa, con la que habían constituido una filial común regida por Derecho societario portugués, que el grupo francés hubiera incumplido la obligación de no competencia, en virtud de la cual le estaba prohibido ejercer sus actividades en Portugal en el ámbito del acuerdo suscrito, salvo que lo hiciera a través de la filial común. Ahora bien, ¿era conforme esta cláusula de no-competencia con el Derecho europeo de la competencia? La primera cuestión que se planteó al tribunal arbitral fue la de la arbitrabilidad de los litigios que ocasionan la aplicación del Derecho comunitario de la competencia: La respuesta fue positiva. La segunda cuestión a resolver por el tribunal arbitral era la de saber si la filial común era una empresa concentrativa o cooperativa y, por consiguiente, si el problema de la compatibilidad de la cláusula de no-competencia con el Derecho comunitario de la competencia debía ser resuelto conforme al —entoncesvigente Reglamento para las operaciones de concentración (Reglamento 4.064/89) o conforme al art. 81 del Tratado, sabiendo que dicho Reglamento se aplicaba a las empresas comunes concentrativas; mientras que el art. 81 TCE se aplica a las empresas comunes cooperativas. Apoyándose en una Comunicación de la Comisión, el tribunal arbitral llegó a la conclusión de que se trataba de una empresa común cooperativa, cuya compatibilidad con el Derecho comunitario de la competencia debía ser apreciada conforme al art. 85 TCE. La tercera cuestión que debió resolver el tribunal arbitral fue la compatibilidad efectiva de la cláusula de no-competencia con el art. 81 del Tratado. En este punto, el órgano arbitral concluyó que dicho acuerdo no era susceptible de restringir sensiblemente la competencia y que, en todo caso, aunque la conclusión hubiera sido otra, no por ello su efecto sobre la estructura del mercado dejaría de ser ampliamente positivo. 
das del Derecho europeo de la competencia y consideró una infracción del art. 81.1 TCE varias disposiciones del reglamento general de una asociación de empresas de Amsterdam - la Centraal Bureau voor de Rijwielhandel_- que regulaba de manera detallada la distribución y el servicio postventa de bicicletas y artículos conexos en Holanda, y que, entre otros extremos, excluía la jurisdicción civil ordinaria en tanto que el procedimiento tuviese por objeto la aplicación de la interpretación de las disposiciones de su Reglamento general.

La Centraal Bureau voor de Rijwielhandel (CBR) era una asociación con sede en Amsterdam que agrupaba a fabricantes, mayoristas e intermediarios de bicicletas, piezas y accesorios de éstas, a los minoristas y reparadores de bicicletas y los comerciantes de artículos para bicicletas. Esta asociación de empresas tenía como objeto promover el comercio de bicicletas, piezas y accesorios de aquéllas y defender los intereses profesionales comunes a sus miembros. Además de un Reglamento interior y de un Reglamento de apelación, la CBR elaboró un Reglamento general, cuya última reforma se produjo en 1976. En dicho Reglamento general, se disponía, de manera muy meticulosa, un régimen colectivo de transacciones en virtud del cual se establecía la obligación de respetar las diferentes funciones de distribución, la obligación de respetar los acuerdos de exclusividad existentes, un sistema colectivo de precios impuestos, el régimen de los descuentos y de los métodos de ventas e, incluso, un sistema de sanciones para los integrantes de la asociación que no respetasen tales disposiciones (advertencias, multas, difusión a través de la radio o de la prensa de las medidas adoptadas con expresa mención del infractor). Las decisiones tomadas con base en el Reglamento general, podían ser impugnadas ante una Comisión de apelación, con exclusión de toda jurisdicción civil ordinaria. Entre 1971 y 1974, la Comisión recibió denuncias e informaciones contra CBR y le advirtió de la necesidad de adaptar su Reglamento general a las exigencias del art. 81 TCE. A pesar de este apercibimiento, la Comisión verificó que CBR mantuvo el sistema colectivo de exclusivas, obstaculizó las importaciones intracomunitarias e, incluso, acudió a los tribunales para exigir el pago de alguna multa. Finalmente, tras varias reuniones en las que no se llegó a ningún acuerdo, la Comisión declaró contrarias al art. 81 TCE numerosas disposiciones del Reglamento general de CBR y rechazó la solicitud de exención individual presentada, en el transcurso de una audiencia celebrada el 27 de julio de 1976, por esta asociación de empresas holandesa. El Reglamento general, en palabras de la propia Comisión, constituía «un sistema coherente y cuidadosamente puesto a punto que restringe sensiblemente la competencia». Una pieza nada desdeñable de este sistema la componía la privación a las empresas, por el Reglamento de recursos de 
la CBR, de la posibilidad de dirigirse a una jurisdicción ordinaria. En efecto, tal como subrayó la Comisión: «... no puede excluirse que la Comisión de apelación (Hoger Beroep) de la CBR interprete las disposiciones del Reglamento general restrictivas de la competencia en un sentido que excedería su contenido objetivo y que disminuiría, retrasaría o entorpecería las garantías jurídicas que las partes contratantes pueden legítimamente esperar; que el cobro de las multas y la supresión de la autorización pueden causar desventajas considerables en la competencia a las empresas interesadas...; que dado que el reglamento general prevé que las personas y sociedades autorizadas deben observar las disposiciones legales y en especial las relativas a la competencia desleal..., existe, por consiguiente, el peligro de que las actividades competitivas deseables en el interés común sean impedidas por la práctica administrativa de la Comisión de apelación, que subsistan distorsiones de la competencia en el Mercado común y que la aplicación del Derecho de la competencia prevista por el Tratado instituyente de la CEE sea eludida...; que la disposición que prevé la exclusión de la jurisdicción ordinaria cae, en su forma actual, bajo el art. 81.1 TCE en tanto que ésta se refiere a hechos que tienen por objeto la aplicación y la interpretación de las reglas de competencia del Tratado y a través de ellas prácticas competitivas permitidas en sí mismas son prohibidas; que los efectos restrictivos de la competencia que derivan o pueden derivar del Reglamento general son reforzados por las disposiciones del Reglamento de apelación». Son dos, pues, los motivos que, en última instancia, han empujado a la Comisión a excluir la validez de la cláusula de exclusión del recurso a un proceso ante tribunal estatal: la prohibición de denegación de justicia —o, si se prefiere, el temor a la indefensión de las empresas integrantes de la CBR-y la desconfianza ante la Comisión de apelación de esta asociación de empresas holandesa, guardia pretoriana de los intereses comerciales de esta organización empresarial más que defensora de la libre competencia en el interior del Mercado común (Dec.Com. 2 de diciembre de 1977, Centraal Bureau voor de Rijwielhandel, JO L 20 de 25 de enero de 1978).

27. b) Más frecuentemente, la Comisión concedió una exención individual en virtud del art. 81.3 TCE, subordinándola al cumplimiento de varias obligaciones por las partes beneficiarias, especialmente la comunicación de cualquier sentencia arbitral que se pudiese dictar con motivo de una diferencia en torno a la interpretación o ejecución del acuerdo objeto de exención ${ }^{56}$.

56 Vid. Dec.Com. de 27 de junio de 1967, Transocéan Marine Paint Association, JO L 163 de 20 de julio de 1967; Dec.Com. de 23 de diciembre de 1971, Henkel-Colgate, JO L 14 de 
Tal fue el caso, ad ex., de la sociedad Campari-Milano SpA, que tenía su sede en Milán, era la titular de las marcas internacionales Bitter Campari y Cordial Campari, con las que se distinguían en el mercado aperitivos fabricados con la ayuda de ciertos concentrados secretos (mezclas especiales de hierbas pulverizadas). Para fomentar la explotación de sus marcas en el extranjero, Campari-Milán constituyó una red de licenciatarios encargados de la fabricación y venta de sus productos. La actividad de las empresas licenciatarias en el interior del Mercado común estaba regulada por los contratos de licencia, que fueron notificados a la Comisión.

Esta tuvo, pues, conocimiento directo de las cláusulas pactadas, que eran las habituales en este tipo de contratos: Campari-Milán se comprometía a no fabricar por sí misma sus aperitivos, durante la validez de los contratos, en el territorio de sus licenciatarios, éstos estaban obligados a no interesarse por otros productos competidores, en especial ciertas bebidas denominadas bitter o bebidas gaseosas similares al Campari Soda, los licenciatarios se comprometieron a no emprender ninguna política activa de venta y a no establecer sucursales ni efectuar ninguna publicidad fuera de los territorios respectivamente concedidos y Campari-Milán se obligó a lo mismo en el interior de estos territorios, etc.

Los contratos de licencia contenían una cláusula previsora del medio de arreglo de diferencias entre las partes, según la cual toda diferencia relativa a la interpretación y ejecución de los contratos sería resuelta por tres árbitros que obrarán como amigables componedores. Se disponía también que normalmente el arbitraje tendría lugar en Milán, salvo en uno de los contratos que preveía que el arbitraje podría tener lugar fuera de la Comunidad y, en especial, en Suiza.

Solicitada una exención individual de la Comisión para cinco contratos de licencia, ésta la concedió, tras procederse por las empresas interesadas a los cambios de los contratos de licencia solicitados por la Comisión. La resolución final impuso expresamente a las empresas implicadas la obligación de comunicar sin demora a la Comisión toda sentencia dictada con base en la cláusula de arbitraje. La Comisión justificó esta exigencia en virtud de tres razones:

18 de enero de 1972; Dec.Com. de 26 de julio de 1972, Papier Mince, JO L 182 de 10 de agosto de 1972; Dec.Com. 18 de julio de 1975, Kabelmetal-Luchaire, JO L 222 de 22 de agosto de 1975; Dec.Com. 15 de diciembre de 1975, Bayer-Gist, JO L 30 de 5 de febrero de 1976; Dec.Com. 25 de julio de 1977, De Laval-Stork, JO L 215 de 23 de agosto de 1977; Dec.Com. 23 de noviembre de 1977, GEC-Weir Sodium, JO L 327 de 20 de diciembre de 1977; Dec.Com. 23 de diciembre de 1977, Campari, JO L 70 de 13 de marzo de 1978; Dec.Com. 13 de julio de 1983, Rockwell/Iveco, JO L 224 de 17 de agosto de 1983. 
a') Existe el riesgo de una interpretación de los contratos que no tenga en cuenta el alcance de la exención individual. Esto podría obligar a la Comisión a modificarla, si ese supuesto se produjera.

b') El procedimiento de arbitraje expone más que el procedimiento judicial normal al «riesgo de una interpretación de los contratos que exceda de los límites de la exención», en particular cuando los árbitros, como en el caso de que se trata, obran en calidad de amigables componedores y no están obligados a aplicar el Derecho material.

c') El control a posteriori de una sentencia arbitral desde el punto de vista de su «compatibilidad con los arts. 81 y 82 TCE, considerados en tanto que elementos constitutivos del orden público de la CEE, no está asegurada en terceros países» (Dec.Com. 23 diciembre 1977, Campari, JO L 70 de 13 de marzo de 1978).

28. Con motivo de la elaboración de un Reglamento de exención por categorías para los acuerdos de licencia de patente, hubo un intento de implantar, con carácter general, la obligación de notificación de cualquier laudo arbitral que pudiera recaer entre las partes ${ }^{57}$. Pero dicho intento no fructificó hasta la adopción del Reglamento (CEE) n. ${ }^{\circ} 4.056 / 86$ de 22 de diciembre de 1986 ( $J O$ L 378 de 31 de diciembre de 1986), por el que se determinan las modalidades de aplicación de los arts. 85 y 86 TCEE (actuales arts. 81 y 82 TCE) a los transportes marítimos (art. 5.5), y del Reglamento n. ${ }^{\circ} 823 / 2000$ de la Comisión de 19 de abril de 2000, relativo a la aplicación del art. 81.3 del Tratado a ciertas categorías de acuerdos, decisiones y prácticas concertadas entre compañías marítimas de línea (consorcios) (DO L 100 de 20 de abril de 2000) (art. 9.4).

Otra cosa es que la Comisión sí tuviese la facultad de solicitar a las empresas la comunicación de las sentencias arbitrales que recayesen sobre un acuerdo exento en virtud del art. 81.3 (Reglamento 2.349/84 para los acuerdos de licencia de patentes [art. 9.1] y Reglamento 556/89 sobre los acuerdos de licencia de know-how [art. 7.1]).

29. c) En el derogado Reglamento (CE) n. ${ }^{\circ} 1.475 / 95$ de la Comisión, de 28 de junio de 1995, relativo a la aplicación del apartado 3 del art. 85 del Tratado a determinadas categorías de acuerdos de distribución y de servicio de venta y de posventa de vehículos automóviles (DOCE n. ${ }^{\circ}$ L 145, 29/6/1985), ad ex., la Comisión condicionó la exen-

57 R. Kovar, «Droit communautaire de la concurrence et arbitrage», en Le droit des relations économiques internationales. Etudes offertes à Berthold Goldman, Paris, 1982, pp. 109-124. 
ción prevista en determinados casos al hecho de que «las partes deberán, en caso de desacuerdo, aceptar un sistema de solución rápida del litigio, tal como el recurso a un perito independiente o a un arbitro, sin perjuicio del derecho de las partes de acudir a la jurisdicción competente, de conformidad con las disposiciones vigentes en la materia en la legislación nacional» (art. 5.3). Se observa, pues, que la Comisión no se opuso a someter a arbitraje cuestiones de Derecho de la competencia ${ }^{58}$.

\section{C) Perspectiva actual (del Reglamento $n .{ }^{\circ} 17$ al Reglamento 1/2003)}

30. Estando en vigor el derogado Reglamento n. ${ }^{\circ} 17$, primer reglamento de aplicación de los arts. 85 y 86 del Tratado (JO n. ${ }^{\circ} 204,21$ de febrero de 1962), se discutió si los árbitros podían aplicar los arts. 85.1, 85.2 y 86 del Tratado CEE ${ }^{59}$. Cuestión ésta que fue resuelta de forma positiva: los asuntos relacionados con el Derecho europeo de la competencia eran, en principio, arbitrables y, por lo tanto, los árbitros podían aplicarles el Derecho europeo de la competencia.

31. El Derecho comunitario establecía dos límites para su aplicación por un árbitro. El primero tenía que ver con las relaciones entre el propio Derecho comunitario y las legislaciones nacionales de los Estados miembros. El segundo era la existencia de una competencia exclusiva por las autoridades comunitarias —en especial, la Comisión, que constituye la guardia pretoriana a la que se le atribuye la misión de velar por la libre competencia en el Mercado único europeo-. Dicho con otros términos, los árbitros se encontraban en una posición similar a la de un órgano judicial de un Estado miembro: No podían aplicar más que las normas de Derecho europeo de la competencia que tuviesen un efecto directo y con respecto a las cuales la Comisión no tuviese asignada una competencia exclusiva ${ }^{60}$.

58 Vid. A. P. Komninos, «Arbitration and the Modernisation of European Competition Law Enforcement«, World Compet., 24 (2), 2001, p. 218.

${ }^{59}$ Los contratos de distribución comercial y los de transferencia de tecnología han propiciado que, en la práctica arbitral, sean más frecuentes los casos en que se ha suscitado la eventual toma en consideración del art. 85 TCEE (actual art. 81 TCE) que del art. 86 TCEE (actual art. 82 TCE). Aunque menos habituales, no faltan casos, sin embargo, en que se recurre al art. 82 TCE. Así, ad ex., en sentencia CCI n. ${ }^{\circ} 7.673 / 1993$, Bull. ICI, n. ${ }^{\circ} 1 / 1995$, pp. 56-59, en un asunto en el que se enfrentaban un demandante francés y un demandado finlandés, el tribunal arbitral, que tenía su sede en Suiza y estaba obligado a aplicar el Derecho suizo al fondo de la controversia, rechazó la excepción del demandado, que alegó la inarbitrabilidad del art. 86 del Tratado de Roma (actual art. 82 TCE), y, con arreglo al Derecho suizo, procedió a resolver el fondo del litigio.

60 Vid., ad ex., B. Hanotiau, L'arbitrabilité, pp. 131-134. 
Por el contrario, no podrían aplicar normas comunitarias desprovistas, en principio, de efecto directo - como es el caso de las Directivas- y su intervención debería limitarse al efecto horizontal (entre particulares) de las normas jurídicas comunitarias con efecto directo.

Los arts. 81 y 82 TCE son normas jurídicas del Derecho europeo de la competencia con eficacia directa (STJCE de 6 de abril de 1962, Soc. Kledingverkoopbedrijf de Geus en uitdenbogerd/Bosch, 13/61, Rec., p. 89), para cuya aplicación no hay más competencia exclusiva que la que a continuación veremos, normas con eficacia sobre las relaciones entre particulares. También, obviamente, tienen eficacia directa los reglamentos comunitarios (art. 249, apartado segundo, TCE), en especial los reglamentos de exenciones por categorías, que tanta importancia tienen en el ámbito del Derecho europeo de la competencia ${ }^{61}$.

32. Como resultado de todo ello, las facultades de que estaba investido un árbitro podían describirse sumariamente del siguiente modo:

1. $\left.{ }^{\circ}\right)$ Desde un punto de vista positivo: El árbitro puede, a título principal o incidental, conocer de la demanda de anulación de un contrato por su contrariedad con el Derecho europeo de la competencia y, sobre todo, fijar la indemnización con la que se repare a un particular el daño causado por un comportamiento anticompetitivo (violación de los arts. 81, 82 o de uno de los Reglamentos comunitarios en esta materia $)^{62}$.

61 Vid., ad ex., sentencia CCI n. ${ }^{\circ}$ 2.811/1978, Clunet, 1979, pp. 983-989, con nota de Y. Derains. Vid., en especial, N. SPIEGEL, Kartellprivatrecht..., pp. 221-225.

62 Vid. W. Abdelgawad, Arbitrage et droit de la concurrence..., pp. 254-271.

Puede considerarse históricamente superada la polémica acerca de si el árbitro sólo era competente cuando se le planteaba la nulidad de un contrato por violación del art. 85 (actual art. 81) del Tratado de Roma con carácter incidental y no cuando conoce a título principal de una demanda que tiene por objeto constatar la nulidad de dicho acuerdo: El árbitro lo es en ambos casos. Entre los defensores de la interpretación más restrictiva figuraban J.-J. BURST, «L'arbitrage dans ses rapports avec les Communautés européennes», Rev. arb., 1979, pp. 105 ss., concr. p. 113; G. VAN HECKE, Arbitrage et règles..., p. 193; J. RoBERT, «Domaine ouvert à l'arbitrage dans le cadre du droit communautaire», Rev. arb., 1966, pp. 23 ss., concr. p. 32. Dicha interpretación tuvo un cierto y limitado eco en la práctica arbitral (vid. los trabajos de la 1. ${ }^{a}$ Comisión del segundo Congreso internacional de arbitraje, Rev. arb., 1966, p. 23, y sobre todo, sentencia CCI n. ${ }^{\circ} 1.397 / 1966$, Clunet, 1974, pp. 879-884, con nota de Y. DeRAINS). En contra, entre los defensores de la interpretación amplia, conforme a la cual la distinción entre conocimiento a título principal o incidental carece de razón de ser, se hallan W. ABdelgawad, Arbitrage et droit de la concurrence..., pp. 241-249; B. Goldman/A. Lyon-Caen/L. Vogel, Droit commercial européen, 5. a ed., Paris, 1994, p. 612; G. HoRmANS, «L'arbitrage et l'ordre public interne belge», Rev. arb., 1978, pp. 79 ss.; P. MAYER, «Le contrat illicite», Rev. arb., 1984, pp. 205-223, concr. pp. 214-215; X. DE MELLO, «Arbitrage et droit communautaire», Rev. arb., 1982, pp. 349 ss. 
2. $\left.{ }^{\circ}\right)$ Desde un punto de vista negativo: El árbitro no puede prohibir comportamientos anticompetitivos (arts. 81 y 82 TCE), imponer multas ordinarias o coercitivas, conceder exenciones individuales (art. 81.3) ni autorizar o prohibir una operación de concentración de empresas o una ayuda de Estado. En los dos primeros casos, por su naturaleza administrativa ${ }^{63}$. En los dos últimos, por ser competencia exclusiva de la Comisión ${ }^{64}$.

33. Ahora bien, en el marco del art. $81 \mathrm{TCE}$, la duda acerca de si los árbitros podían - $\mathrm{O}$ no- aplicar Derecho de la competencia se circunscribió únicamente a los arts. 81.1 y 81.2 TCE. Dicho con otras palabras, estaba claro que, si el Reglamento n. ${ }^{\circ} 17$ facultaba a las autoridades nacionales para emplear los dos primeros párrafos del art. 81 TCE, cabía plantearse la cuestión de saber si los árbitros podrían también emplearlos. En cambio, con respecto al art. 81.3 TCE, como quiera que la normativa comunitaria imponía su exclusiva aplicación por la Comisión, no se cuestionó en ningún momento si los árbitros podrían actuar también respecto de este tercer apartado: Era evidente que la competencia exclusiva de la Comisión para conceder exenciones a la prohibición del art. 81.1 TCE no sólo veta-

Asimismo, carece de sentido distinguir según que los árbitros tengan que pronunciarse sobre un contrato lícito o no. En efecto, puede ocurrir que, como resultado de un juicio provisional emitido por los árbitros, éstos lleguen a la conclusión de que el contrato objeto de examen no infringe el art. $81 \mathrm{TCE}$, es un contrato lícito y, por consiguiente, su arbitrabilidad no es, en modo alguno, cuestionable (ad ex., sentencia CCI n. ${ }^{\circ} 1.397 / 1966$, Clunet, 1974, pp. 879-884, con nota de Y. DeraINS; sentencia CCI n. ${ }^{\circ}$ 2.811/1978, Clunet, 1979, pp. 983-989, con nota de Y. DERAINS). Pero cabe preguntarse qué ocurre si, de ese juicio provisional se infiere que el contrato viola el art. 81 TCE y es, por tanto, un acuerdo nulo. Algunas decisiones arbitrales muy antiguas creyeron que no sólo el contrato principal sería nulo, sino también la cláusula compromisoria y que los árbitros, en todo caso, serían incompetentes para aplicar una normativa de orden público (ad ex., sentencia arbitral de 22 julio 1964, Rev. arb., 1965, p. 28). Pero esta última interpretación, hoy desprestigiada, como ha puesto de relieve P. MAYER, «Le contrat illicite», Rev. arb., 1984, pp. 205-223, subordina la competencia del árbitro a la solución que se le dé a la cuestión de fondo, olvida que la solución a la que llegue el árbitro no sólo tendrá fuerza de cosa juzgada, sino que también la tendrá el motivo por el que se declara incompetente — es decir, la contrariedad a una norma de orden público (el Derecho comunitario de la competencia y, en particular, el art. $85 \mathrm{TCE}$ - - y, por último, ignora la autonomía de la cláusula compromisoria y, por lo tanto, la posibilidad de que el contrato principal y la cláusula compromisoria sigan regímenes jurídicos distintos: Que la nulidad de uno no suponga la de otro y que puedan eventualmente estar sometidos a leyes distintas.

63 Sobre la incompetencia del árbitro para aplicar las disposiciones de naturaleza administrativa y penal, vid., ad ex., W. ABdelgawAD, Arbitrage et droit de la concurrence..., pp. 188-196 y 272-285; G. VAN HECKE, Arbitrage et règles..., pp. 191 y 193.

64 Vid., per omnia, W. ABdELGAWAD, Arbitrage et droit de la concurrence..., pp. 196-200. 
ba el recurso a las autoridades o tribunales nacionales, sino también a los órganos arbitrales.

34. Pero la perspectiva actual ha cambiado. El Reglamento 1/2003, del Consejo, de 16 de diciembre de 2002, relativo a la aplicación de las normas sobre competencia previstas en los arts. 81 y 82 del Tratado (DOCE L 1 de 4 de enero de 2003) es la norma que refleja el cambio de enfoque ${ }^{65}$.

65 Sobre el nuevo régimen jurídico del procedimiento de defensa de la competencia ante la Comisión, vid., ad ex., Chr. Brown/D. HARdiman, «The extent of the Community Institutions' duty to co-operate with national courts: "Zwartfeld" revisited», Eur.Compet.L.Rev., 25, 5, 2004, pp. 299-304; D. CAHILL (Ed.), The modernisation of EU competition law enforcement in the European Union. FIDE 2004 national reports, Cambridge, 2004; M. ${ }^{\mathrm{P}}$. CANEDO ARRILlaGA, «El nuevo procedimiento comunitario de defensa de la libre competencia y su incidencia en el sistema español», Cuadernos Europeos de Deusto, n. ${ }^{\circ} 31$, 2004, pp. 41-80; G. CANIVET, «L'organisation des juridictions nationales pour l'application du droit communautaire de la concurrence», Concurrences, 2004, n. ${ }^{\circ}$ 1, pp. 21-28; J.-M. FAVRET, «Le renforcement du rôle des autorités nationales dans la mise en oeuvre du droit communautaire de la concurrence: le règlement du Conseil n. ${ }^{\circ} 1 / 2003$ du 16 décembre 2002», L'Actualité juridique. Droit administratif, 60, n. ${ }^{\circ}$ 4, 2 février 2004, pp. 177-185; F. GARRIDO RuIz, «Novedades aportadas por el nuevo reglamento n. ${ }^{\circ}$ 1/2003 relativo a la aplicación de las normas sobre competencia previstas en los artículos 81 y 82 CE», Gac.Jur.UE, n. ${ }^{\circ} 231$, 2004, pp. 71-82; L. GARZANiTi/J. Gudofsky/J. Moffat, «Dawn of a new era? Powers of investigation and enforcement under regulation 1/2003», Antitrust L.J., 72, 1, 2004, pp. 159-207; C. Gauer/L. KJolbe/D. Dalheimer/E. De Smijter/D. Schnichels/M. LauriLA, «Regulation 1/2003 and the Modernisation Package fully applicable since 1 May 2004», Competition Policy Newsletter, 2004, 2, pp. 1-6; J.P. GRUBER, «Das neue Kartellverfahren der Europäischen Union», Wirtschaftsrechtliche Blätter, 18, Januar 2004, pp. 1-12; J. HAMER, «Die Durchsetzung der EG-Wettbewerbsregeln im Rahmen der VO 1/2003», ERA-Forum: Script Iuris Europaei, 2004, 1, pp. 7-26; L. IDOT, Droit communautaire de la concurrence: le nouveau système communautaire de mise en oeuvre des articles 81 et 82 $C E$, Bruxelles, Paris, 2004; A.P. Komninos, «Article 234 EC and national competition authorities in the era of decentralisation», Eur.L.Rev., 29, 1, 2004, pp. 106-114; T. KRUMSTROH, Das Weissbuch und der Verordnungsvorschlag der Europäischen Kommission zur Modernisierung der Anwendung der Vorschriften der Art. 81 und 82 EG und deren Einfluss auf nationale Wettbewerbsregeln, Kartellbehörden und Gerichte, Frankfurt am Main, 2004; TH. LAMPERT, EG-KartellVO: Praxiskommentar zur Verordnung (EG) Nr. 1/2003, Heidelberg, 2004; K. LENAERTS/D. GERAD, «Decentralisation of EC competition law enforcement: judges in the frontline», World Compet., 27, 3, September 2004, pp. 313-349; E.-J. MestMÄCKer/H. SchweITZER, Europäisches Wettbewerbsrecht, 2. ${ }^{\text {a }}$ ed., München, 2004, pp. 473-525; G.V.S. MCCURDY, «The impact of modernisation of the EU competition law system on the Courts and private enforcement of the competition laws: a comparative perspective», Eur.Compet.L.Rev., 25, 8, 2004, pp. 509-517; M. MEROLA/M. ${ }^{a}$ MuÑOZ DE JUAN, «Le rôle des juridictions nationales dans le cadre de l'application décentralisée des articles 81 et 82 du Traité CE», J.Trib.(Brux.), vol. 123, n. ${ }^{\circ} 6.153,23$ octobre 2004, pp. 769-779; P. Nihoul (Ed.), La décentralisation dans l'application du droit de la concurrence: un rôle accru pour le practicien, Bruxelles, 2004; C. NOURISSAT/R. WTTERWULGHE (Dirs.), Le nouveau règlement d'application du droit communautaire de la concurrence, 
Con respecto a dicho Reglamento baste señalar que:

$\left.1 .^{\circ}\right)$ Es el resultado de una iniciativa política que obedece al impulso del entonces comisario de la competencia, MARIO MonTI, y de varios compromisos políticos. En 1999, se inició el proceso de modernización de las normas de Derecho de la competencia, un largo camino erizado de dificultades, cuyos primeros pasos fueron el Libro Blanco sobre la modernización de las normas de aplicación de los arts. 85 y 86 TCE (DOCE n. ${ }^{\circ} \mathrm{C} 132$, 12 mayo 1999) y la Propuesta de Reglamento del Consejo relativo a la aplicación de las normas sobre competencia previstas en los arts. 81 y 82 del Tratado, y por el que se modificaban los Reglamentos (CEE) n. $.^{\circ} 1.017 / 68$, (CEE) n. ${ }^{\circ} 2.988 / 74$, (CEE) n. ${ }^{\circ} 4.056 / 86$ y (CEE) n. ${ }^{\circ} 3.975 / 87$ («Reglamento de aplicación de los arts. 81 y 82 del Tratado») (DOCE n. ${ }^{\circ} \mathrm{C} 365,19$ de diciembre de 2000).

2. $\left.{ }^{\circ}\right)$ El giro efectuado con la nueva regulación responde al colapso sufrido por la Comisión como consecuencia de las continuas notificaciones previas recibidas de las empresas. Esta saturación de trabajo llevó a plantear un cambio de sistema: Del sistema de autorización se pasó al sistema de excepción legal y de control a posteriori ${ }^{66}$.

3. $\left.{ }^{\circ}\right)$ Una de las principales novedades que aporta el Reglamento $1 / 2003$ consiste en que, a partir del 1 de mayo de 2004 - fecha de inicio de la aplicabilidad del texto comunitario-, las autori-

\footnotetext{
Paris, 2004; L. Nouvel, «1er mai 2004: l'entrée en vigueur du Règlement 1/2003 et du "Paquet modernisation" portant réforme des règles de mise en oeuvre des articles 81 et 82 CE», Rev.dr.aff.int., 2004, 3, pp. 371-386; K. PIJETLOvIC, «Reform of EC antitrust enforcement: criticism of the new system is highly exaggerated», Eur.Compet.L.Rev., 25, 6, 2004, pp. 356-369; U. Schnelle/A. BARtosch/A. HüBnER, Das neue EU-Kartellverfahrensrecht: Auswirkungen der Verordnung (EG) Nr. 1/2003 auf die Kartellrechtspraxis, Stuttgart, 2004; F. SCHÖLER, Die Reform des europäischen Kartellverfahrensrechts durch die Verordnung (EG) Nr. 1/2003, Frankfurt am Main, 2004; J. Schwarze/A. WeitBrecht, Grundzüge des europäischen Kartellverfahrensrechts: die Verordnung (EG) Nr. 1/2003, Baden-Baden, 2004; R. WAINWRIGHT, «The relationship between the national judge and the European Commission in applying Articles 81 and 82 of the EC Treaty», ERA-Forum: scripta Iuris Europaei, 2004, 1, pp. 84-91; PH. WARD, «Rating enforcement», Global Competition Review, 7, 3, 2004, pp. 4-40; J. ZwIEnER, Die Auswirkungen der Verordnung Nr. 1/2003 auf das europäische und deutsche Kartellverfahren, Frankfurt am Main, 2005.

66 Según el Libro Blanco, apartado 76, «en un sistema de excepción legal, las empresas quedan descargadas de la obligación de notificar y disponen de un medio de defensa suplementario en los tribunales para obtener la ejecución de sus acuerdos, ya que pueden alegar la aplicación del artículo 85.3».
} 
dades nacionales de competencia y los órganos jurisdiccionales nacionales pueden aplicar el entero art. 81 TCE, con su tercer párrafo incluido (arts. 5 y 6 Reglamento 1/2003, respectivamente). La Comisión, desde ese momento, debería concentrarse en luchar contra las infracciones más graves del Derecho de la competencia (Libro Blanco, apartado 42).

4. $\left.{ }^{\circ}\right)$ Como consecuencia del giro copernicano experimentado por el Derecho europeo de la competencia a causa del Reglamento $1 / 2003$, una visión panorámica de dicho ordenamiento jurídico necesariamente se parecería mucho al cuadro fino e irónico que ha descrito un jurista suizo: «Mientras, hasta ahora, la música del Derecho europeo de la competencia era tocada básicamente por la Comisión como un solista, pronto será una orquesta de 15 a 25 músicos quienes toquen esta música compuesta por el Tratado Constitutivo de la Comunidad Europea, con arreglos de la Comisión, con algunas letras del Tribunal de Justicia de la comunidad Europea y del Tribunal de Primera Instancia. No siendo una sorpresa, el director de esta orquesta será la Comisión, y la Comisión tiene reservado el derecho a tocar el primer violín cuando el interés público así lo exija. Sin embargo, si bien esta nueva orquesta - con músicos de Portugal a Polonia, Malta y Chipre- tocará afinadamente y de acuerdo con los mismos compases, será objeto de vigilancia. Los tribunales arbitrales, aunque básicamente tocan el mismo tipo de música, no forman parte de esta nueva orquesta. Ellos tocan música de cámara, sin un director, y con especiales solistas que habrán estudiado su parte con el máximo cuidado» ${ }^{67}$.

35. Por consiguiente, cabría preguntarse, tras la entrada en vigor del Reglamento 1/2003, si los árbitros, que evidentemente no son ni autoridades nacionales de competencia ni órganos jurisdiccionales nacionales, podrían pronunciarse en relación con el art. 81.3 - por analogía con la posibilidad que el Reglamento 1/2003 ofrece a los órganos jurisdiccionales-. Expresado con otros términos, se trata de saber si, como ya ocurrió a propósito de los arts. 81.1, 81.2 y 82 TCE, un órgano arbitral dispone de las mismas facultades que un órgano judicial de un Estado miembro para declarar la existencia de una exención en virtud del art. 81.3 TCE.

67 M. BLESSING, Arbitrating Antitrust and Merger Control Issues, Helbing \& Lichtenhahn, Zürich, 2003, p. 16. 
36. Existen cuatro posibles - y rotundas - razones para justificar que los árbitros puedan aplicar el art. 81 TCE en su totalidad ${ }^{68}$ :

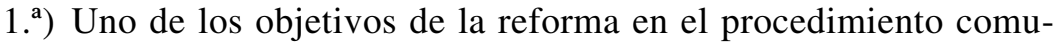
nitario es la aplicación integral del art. $81 \mathrm{TCE}$, ya sea por parte de los órganos jurisdiccionales o por parte de los árbitros. La Comisión, desde la adopción del Libro Blanco, ha buscado conseguir que los órganos competentes para aplicar el art. 81 TCE, lo sean para aplicarlo en su totalidad: Lo de menos es determinar quiénes son los competentes, lo importante es que esos órganos puedan aplicar todo el art. 81 TCE, y no sólo algunos apartados del mismo ${ }^{69}$.

2. $\left.{ }^{a}\right)$ La función que desarrollan los árbitros es similar a la que llevan a cabo los órganos jurisdiccionales. Esta naturaleza jurisdiccional de la labor arbitral hace que la posición de los árbitros se pueda equiparar a la que tienen los órganos jurisdiccionales a la hora de aplicar los arts. 81 y $82 \mathrm{TCE}^{70}$. El hecho de que la nueva regulación en materia de competencia no mencione a las instancias arbitrales como órganos competentes para aplicar las normas de Derecho europeo de la competencia, puede deberse a que la Comisión haya estimado que no era necesaria su inclusión. Si la Comisión hubiera querido que los árbitros no fueran competentes para la aplicación del art. 81.3 TCE, habría dispuesto una disposición expresa, excluyendo a estos órganos como autoridades competentes en este sentido.

3. $\left.{ }^{a}\right)$ Una de las principales ventajas del arbitraje es su celeridad. Si el árbitro no pudiese aplicar el art. 81.3 TCE, a la hora de resolver los casos de ententes planteados ante él, y ante la imposibilidad de plantear una cuestión prejudicial al TJCE, sólo le quedaría recurrir a los jueces para que éstos le dijesen si concurren las condiciones de exención del tercer párrafo del art. 81. Esta suspensión del proceso arbitral y subsiguiente pregunta a los órganos jurisdiccionales nacionales retrasaría en exceso la solución del caso y perjudicaría una de las principales ventajas del arbitraje: la rapidez. Esta única opción que le quedaría al árbitro, en realidad, no sería una vía efectiva en todo caso, ya

$68 \mathrm{~W}$. ABdelgawAD, «L'arbitrage international et le nouveau règlement d'application des articles 81 et 82 CE». Rev. arb., n..$^{\circ}$ 2, 2004, pp. 256-260.

69 Vid. L. IDOT, «Arbitration and the Reform of Regulation 17/62», en C.-D. EHLERMANN/ I. AtANASIU (eds.), European Competition Law Annual: 2001, Effective Private Enforcement of EC Antitrust Law, Hart Publishing, Oxford, 2003, p. 317.

70 Ibidem, p. 316. 
que, no existen mecanismos previstos de colaboración entre los árbitros y los órganos jurisdiccionales en este sentido. Además, nada garantiza que la aplicación del art. 81.3 TCE por parte de un juez sea siempre más acertada que la que pueda realizar un árbitro. No hay razones, entonces, para que los árbitros no puedan ser órganos competentes en relación con el art. 81.3 TCE.

4. $\left.{ }^{a}\right)$ La reforma también tiene como finalidad favorecer la privatización del Derecho de la competencia. En efecto, salvo que el asunto tenga un interés comunitario superior, los particulares acudirán a las jurisdicciones nacionales y a las autoridades nacionales de competencia para dirimir sus controversias, siendo éstos los órganos que se encuentran mejor situados para defender los derechos subjetivos de los particulares recogidos en el art. 81 TCE (Considerando 7 Reglamento 1/2003). Suponer la arbitrabilidad del Derecho europeo de la competencia, abunda en la consecución de este objetivo de privatización.

\section{Aplicación del Derecho de la competencia por los árbitros: Facultativa u obligatoria}

37. Puede suceder — es lo más habitual— que una de las partes invoque, en el transcurso del procedimiento arbitral, las normas sobre libre competencia - en particular, los arts. 81 y 82 TCE o un Reglamento comunitario - y entonces no quepa plantearse la aplicabilidad de oficio o a instancia de parte del Derecho europeo de la competencia por los árbitros. Pero también puede ocurrir que ninguna de las partes lo alegue, bien sea intencionadamente o por error, o que — supuesto menos frecuentelas partes excluyan la aplicabilidad por los árbitros del Derecho de la competencia en la misma cláusula compromisoria o en el transcurso del procedimiento arbitral: Es sólo, en estos últimos casos, cuando surge, con toda su trascendencia, la cuestión de si un órgano arbitral está obligado a aplicar, de oficio, el Derecho europeo de la competencia ${ }^{71}$.

38. El árbitro internacional no sólo está facultado, sino que está obligado a tener en cuenta e, incluso, aplicar, en su caso, el Derecho de la competencia, en general, y el Derecho europeo de la competencia, en particular, como se recuerda tanto por algunos autores ${ }^{72}$ como por la

71 N. SPIEGEL, Kartellprivatrecht..., pp. 120-127.

72 W. ABDELGAWAD, Arbitrage et droit de la concurrence..., pp. 286-294; M. DE BoISSÉSON, Le droit français de l'arbitrage interne et international, Paris, 1990, pp. 509-510; 
propia práctica arbitral, en especial de la Cámara de Comercio Internacional $^{73}$. El principal motivo que se alega en favor de esta interpretación se halla en la naturaleza de orden público o, si se prefiere, el carácter absolutamente imperativo de los arts. 81 y 82 TCE y, en general, del Derecho europeo de la competencia ${ }^{74}$.

39. Frente a la anterior afirmación, un sector doctrinal ha sostenido que los árbitros no se encuentran, en principio, obligados a aplicar las normas de competencia. No son autoridades nacionales ni órganos jurisdiccionales y, por consiguiente, no son destinatarios de los arts. 81 y 82 TCE. Es más, la aplicabilidad de oficio del Derecho europeo de la competencia — se ha observado- podría suponer que el laudo arbitral estuviese viciado por incongruencia: Los árbitros podrían resolver ultra petita, si se respaldaran en las normas sobre libre competencia, atribuyéndose así una misión que no les fue atribuida por las partes, especialmente en el supuesto de que éstas hubieran decidido la exclusión de tales normas ${ }^{75}$.

A la postre, este sector doctrinal no se encuentra, sin embargo, tan alejado del primero como se pudiera pensar; ya que también se ha señalado que si los árbitros no están vinculados jurídicamente, sí lo están en la práctica, puesto que, para evitar que los laudos que dicten puedan ser

R. KovAR, «Droit communautaire de la concurrence et arbitrage», en Le droit des relations économiques internationales. Etudes offertes à Berthold Goldman, Paris, 1982, pp. 109-124; J.-H. MoITRY, Arbitrage international..., p. 11; C.M. SCHMITTHOFF, «Arbitration and EEC Law», C.M.L.Rev., 24, 1987, pp. 143-157, concr. p. 146.

73 Vid., ad ex., el «Rapport sur l'arbitrage et le droit de la concurrence», Swiss Review of International Competition Law, 1984, pp. 37 ss.; así como, ad ex., sentencia arbitral de

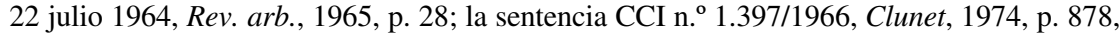
con nota de Y. Derains; sentencia CCI n. ${ }^{\circ}$ 2.811/1979, Clunet, 1979, p. 984, con nota de Y. Derains; sentencia CCI n. ${ }^{\circ} 6.503 / 1990$, Clunet, 1995, p. 1.022, nota de Y. Derains; sentencia CCI n. ${ }^{\circ} 6.614 / 1991$, Bull. ICC, n. ${ }^{\circ} 1 / 1995$, pp. 53-54; sentencia CCI n. ${ }^{\circ} 7.673 / 1993$ comentada por Y. DERAINS, «L'application du droit européen par les arbitres - Analyse de la jurisprudence», en R. BRINER/Y. DeRAINs [et al.], L'arbitrage et le Droit Européen, Bruylant, Bruxelles, 1997, pp. 65-80, concr. pp. 70 y 75; sentencia CCI n. ${ }^{\circ}$ 7.539/1996, Clunet, 1996, p. 1.030, nota de Y. DeRAins.

${ }^{74}$ N. SPIEGEL, Kartellprivatrecht..., pp. 124-127.

75 P. MAYER, «Le contrat illicite», Rev. arb., 1984, pp. 205-223, concr. p. 215. En contra de esta opinión, cabe observar que: En primer lugar, la regla de orden público está demasiado estrechamente unida a la propia sustancia de la obligación contractual para que pueda ser considerada exónena al objeto del litigio (J.-H. MoITRY, Arbitrage international..., p. 11). En segundo lugar, los árbitros tienen la obligación de considerar todas las cuestiones que sean de orden público en interés de las propias partes, que les han otorgado su confianza, si no quieren arriesgarse a que su sentencia sea anulada por no haber aplicado o haber aplicado incorrectamente una norma de orden público (X. DE MELLO, «Arbitrage et droit communautaire», Rev. arb., 1982, pp. 349 ss., concr. p. 362). 
objeto de nulidad o de no reconocimiento deberían observar las prescripciones del Derecho de la competencia de oficio ${ }^{76}$. En efecto, para dotar de verdadera fuerza vinculante al laudo arbitral, éste no debería contradecir el orden público de los Estados de la UE, y, para esto, los árbitros deben respetar las normas de competencia aplicables en el caso $^{77}$.

40. La obligación de aplicar las normas de competencia de oficio, sin embargo, sólo debería existir:

1. $\left.{ }^{\circ}\right)$ En los casos en los que el laudo arbitral dictado hubiera de ser ejecutado en territorio comunitario, ya que, en estos supuestos es cuando el juez nacional comunitario que concede la ejecución debe comprobar que el laudo no atenta contra el orden público (Vorrang des Kartellrechts des Vollstreckungstaates) ${ }^{78}$. Si la sentencia arbitral debiera ser ejecutada fuera de la UE, el órgano jurisdiccional al que se solicitara la misma, aplicaría sus normas, no el Derecho comunitario, y, por tanto, normalmente no se denegaría la ejecución por el incumplimiento de los arts. 81 y 82 del Tratado (back-stage-door escape $)^{79}$.

2..$\left.^{\circ}\right)$ Obviamente, cuando el Derecho aplicable al contrato que origina la diferencia entre las partes es el Derecho de un Estado miembro de la UE, el órgano arbitral tiene el deber de aplicar las reglas de orden público del Derecho comunitario de la competencia (Prinzip vom Vorrang der lex causae) ${ }^{80}$, habida cuenta de su efecto directo en el Derecho interno y deben hacerlo de oficio, incluso ante la falta de alegación por las propias partes (ad ex., J.-J. ARNÁLDEZ) ${ }^{81}$ : Conocida como teoría del estatuto

76 Vid. W. Abdelgawad, L'arbitrage international et le nouveau Règlement..., pp. 261-263.

77 Vid. A. P. Komninos, «Arbitration and the Modernisation of European Competition Law Enforcement», World Compet., 24 (2), 2001, p. 237.

78 N. SPIEGEL, Kartellprivatrecht..., pp. 95-96.

79 Vid. L. IDOT, «Arbitration and the Reform of Regulation 17/62», en C.-D. EHLERMANN/ I. AtAnAsiu (eds.), European Competition Law Annual: 2001, Effective Private Enforcement of EC Antitrust Law, Hart Publishing, Oxford, 2003, pp. 313-315; F.-B. WeIGAND, «Evading EC Competition Law by Resorting to Arbitration?», Arbitration International, 1993, pp. 249-258.

80 N. SPIEGEL, Kartellprivatrecht..., pp. 88-94.

81 Así ocurrió, ad ex., en el caso resuelto por sentencia CCI n. ${ }^{\circ} 8.423 / 1998$, Clunet, 4 , 2002, pp. 1.079-1.085, con nota de J.-J. ARNÁLDEZ. Como señala este comentarista, no había ninguna duda de la aplicabilidad de la reglamentación comunitaria: El arbitraje se desarrollaba en Bruselas, las partes habían elegido el Derecho portugués, las sociedades litigantes eran de Estados comunitarios (Portugal y Francia) y el contrato debía ser ejecutado en territorio comunitario. 
obligacional (Schuldstatutstheorie), esta posible interpretación significa que los tribunales arbitrales deben aplicar a la diferencia entre las partes el Derecho material de la lex causae (el Derecho rector del fondo del asunto, generalmente un contrato) en su conjunto, incluidas las normas imperativas del Derecho económico $^{82}$. A las partes se les debe permitir que expresen sus puntos de vista, para que, así, el principio de contradicción sea respetado (W. Abdelgawad, Y. Derains, J.-B. Racine) ${ }^{83}$.

41. Está, pues, claro que, inicialmente, un árbitro que cumple su labor en un Estado no comunitario y conforme a una legislación no comunitaria no está obligado de oficio a tomar en consideración el Derecho antitrust comunitario. Pero cabe preguntarse si, aun así, pudiera aplicarlo o, al menos, intentarlo (Berücksichtigung des Kartellrechts dritter Rechtsordnungen) ${ }^{84}$. Es ésta una cuestión de alcance más general, una cuestión que puede plantearse a propósito de la conveniencia de que los árbitros tomen en consideración las leyes de policía de determinados Estados (drittstaatliche Eingriffsnormen), sean o no de libre competencia ${ }^{85}$. Los autores han estado divididos y la práctica de los tribunales arbitrales no lo ha estado menos.

Es significativo el hecho de que la práctica arbitral en Suiza haya experimentado un giro copernicano durante los años 90 . Como ha subrayado, entre otros, M. BLESSING, mientras que, hasta finales de los años 80, los tribunales arbitrales suizos mostraban generalmente su rechazo a aplicar normas antitrust que no perteneciesen a la lex causae, su actitud cambió claramente en los años siguientes y se consideraron competentes para verificar la compatibilidad de un contrato con los arts. 81 y 82 TCE $^{86}$.

82 W. Abdelgawad, Arbitrage et droit de la concurrence..., pp. 357-362; J.-B. RACINE, L'arbitrage commercial international..., pp. 239-269; N. SPIEGEL, Kartellprivatrecht..., p. 204.

${ }^{83}$ Sentencia CCI n. ${ }^{\circ} 7.539 / 1995$, Clunet, 1996, pp. 1.030-1.037, con nota de Y. DERains; W. AbDelgawad, Arbitrage et droit de la concurrence..., p. 292; J.-B. RACINE, L'arbitrage commercial international..., p. 289.

${ }^{84}$ N. SPIEGEL, Kartellprivatrecht..., pp. 97-106.

85 J.-B. RACINE, L'arbitrage commercial international..., pp. 298-350; N. SPIEGEL, Kartellprivatrecht..., pp. 207-212.

${ }^{86}$ Un caso excepcional fue la decisión de la Chambre des Recours del Cantón de Vaud de 28 de octubre de 1975, en el caso Ampaglas v. Sofia (publicada en el Journal des Tribunaux, 129, 1981-III-71), que afirmó la competencia de un árbitro para examinar la validez de un contrato a la luz de los (entonces) arts. 85 y 86 del Tratado de Roma. Ya en los años 90, el leading case es el resuelto por la decisión del Tribunal Supremo Federal Suizo de 28 de abril de 1992, in re G. SA v. V. SpA (publicada en ATF 118 II 193), que sostuvo la competencia de los tribunales arbitrales con sede en Suiza para pronunciarse sobre la compati- 
Incluso, en algunos casos, se confirma la aplicación de oficio de las normas de Derecho europeo de la competencia en relación con demandas sobre contratos en los que no se ha designado Derecho aplicable ${ }^{87}$.

42. Las situaciones en las que un árbitro debería tener en cuenta las normas del Derecho europeo de la competencia, aunque el contrato estuviese regido por la ley de un ordenamiento no comunitario (=Anwendung kartellrechtlicher Normen einer anderen Rechtsordnung als der lex causae), serían, pues las siguientes (G. BLANKE):

1. a) Cuando las disposiciones imperativas de libre competencia pertenezcan al Derecho que resultaría aplicable en caso de que las partes no hubieran elegido una ley para su contrato.

2. a) Cuando el contrato esté estrechamente vinculado con el Estado al que pertenecen esas normas de libre competencia.

3. $\left.{ }^{a}\right)$ Cuando la ejecución del laudo arbitral pueda no ser efectiva por no haberse respetado las disposiciones del Derecho europeo de la competencia ${ }^{88}$.

43. Por su parte, el Tribunal de Justicia tuvo que resolver dos cuestiones parcialmente relacionadas con la anterior. Primera: Si las normas comunitarias de competencia son aplicables de oficio por el tribunal estatal que tiene que controlar una sentencia arbitral, cuestión ésta a la que ha dado una respuesta positiva. Segunda: si las normas procesales internas relativas a la fuerza de cosa juzgada que impiden el examen de la compatibilidad de un laudo arbitral con el art. 81 TCE son compatibles con el Derecho comunitario, cuestión a la que, en el caso concreto

bilidad de un contrato con las normas sobre competencia de la CE, contrato de cooperación e inversión entre un grupo belga y varias empresas italianas, que se regía por el Derecho belga y en el que se dividían los territorios de compra y venta y se incluían acuerdos sobre precios. Después de este caso, tribunales arbitrales suizos afirmaron dicha competencia, incluso en casos en que la legislación aplicable elegida por las partes no era la de un Estado comunitario. Así, ad ex., la sentencia CCI n. ${ }^{\circ}$ 7.673/1993, Bull. ICI, n. ${ }^{\circ}$ 1/1995, pp. 56-59, en un caso en el que el contrato litigioso se regía por el Derecho suizo, sostuvo que: «It is generally agreed that under Article 187(1) PIL, arbitrators must or at least may observe the international public policies of other States or of the European Communities irrespective of the substative law applicable». Vid. M. BLESSING, Introduction to Arbitration - Swiss and International Perspectives, Basel, 1999, pp. 246-248.

87 Así, en el asunto n. ${ }^{\circ}$ 8.030/1995, los árbitros analizaron de oficio si el contrato de concesión en litigio se podía acoger a la excepción del artículo 85.3 Tratado de Roma. Se trataba de un contrato entre un concedente ruso y un distribuidor sueco. La demanda se interpuso por entender el distribuidor que la otra parte no había protegido el mercado español de las importaciones paralelas de vehículos del concedente.

88 G. Blanke, «The Role of EC Competition Law...», pp. 179-180. 
de que se trataba, se le ha dado también una respuesta positiva. En efecto, la STJCE de 1 de junio de 1999, Eco Swiss China Time Ltd/Benetton International NV, Rec., p. I-3055, arrojó luz sobre los dos problemas mencionados ${ }^{89}$.

44. Conviene, pues, que nos refiramos a los hechos que dieron origen al caso Benetton. Son los siguientes: La sociedad Benetton international, con sede en Amsterdan, concluyó un contrato de licencia con Eco Swiss China Time, sociedad con sede en Hong Kong, a la que se autorizaba a fabricar y vender relojes con la inscripción «Benetton by Bulova». Conforme a una cláusula compromisoria prevista en dicho contrato, se inició un procedimiento arbitral por ruptura anticipada del contrato, ya que Benetton lo rescindió tres años antes de su término final. El arbitraje se realizó en el Instituto holandés de arbitraje y conforme al Derecho holandés. El tribunal arbitral dictó dos laudos relacionados con este caso. En el primero de ellos, se ordenaba a Benetton que indemnizase a su empresa licenciataria por los perjuicios que la resolución anticipada del contrato le había producido. El segundo laudo, tuvo que dictarse, ante la falta de acuerdo de las partes, para fijar la cuantía de la indemnización. Aunque nunca lo alegó en el transcurso del procedimiento arbitral, Benetton invocó, como argumento para obtener la nulidad de ambas sentencias arbitrales, ante un tribunal estatal holandés, la nulidad del contrato de licencia por ser éste, en su opinión, contrario al Derecho comunitario de la competencia. En apelación, ganó Benetton: el tribunal holandés anuló el laudo arbitral, por entender que el art. 81 del Tratado de Roma, en el que se prohíben las ententes, es una norma de orden público en el sentido del ordenamiento jurídico holandés. En casación, el Tribunal Supremo holandés planteó cinco cuestiones prejudiciales al TJCE, que, en realidad, son reconducibles a dos temas: la aplicabilidad de oficio del art. 81 TCE a los laudos arbitrales que ya han sido pronunciados y la compatibilidad - o no- de las normas procesales holandesas que regulan el control jurisdiccional de los laudos arbitrales con la validez del Derecho europeo de la competencia. Veamos cada uno de ellos:

89 STJCE de 1 de junio de 1999, Eco Swiss China Time Ltd/Benetton International NV, C-126/97, Rec., p. I-3055, apartados 35, 36, 40, 45 y 46. Vid., ad ex., S. Poillot PeruZzeTO, «L'ordre public international en droit communautaire. À propos de l'arrêt de la Cour de justice des Communautés du 1.er juin 1999 (affaire Eco Swiss China Time Ltd)», Clunet, 2000, 2, pp. 299-307; C. PRIETO, «Note sous CJCE 1.er juin 1999, C-126/97, Eco Swiss China Time/Benetton International», Clunet2000, 2, pp. 504-506; P. ZoBEL, «Art. 81 EGV im Schiedsgerichtsverfahren», Wirtschaftsrechtliche Blätter, 15, Juli 2001, pp. 300-307. 
45. a) Gracias al Convenio de Nueva York de 10 de junio de 1958 sobre reconocimiento y ejecución de sentencias arbitrales extranjeras, es poco probable que un tribunal estatal pueda, de oficio, no reconocer un laudo arbitral extranjero. En el caso de que se trataba, la única posibilidad de anular la sentencia arbitral radicaba en saber si la sentencia o la manera en que ha sido dictada es contraria al orden público o a las buenas costumbres (art. 1.065 del Código holandés de procedimiento civil). Cabía, pues, preguntarse si el art. 81 TCE podía efectivamente considerarse una disposición de orden público. El Tribunal de Justicia puso de relieve estos datos de interés:

1..$\left.^{\circ}\right)$ El art. 81 TCE instituye una disposición fundamental para el funcionamiento del Mercado interior, hasta el punto de que los acuerdos constitutivos de una entente ilícita son nulos de pleno derecho.

2..$\left.^{\circ}\right)$ Dado que, en consecuencia, no cabe discutir la calificación de dicho precepto como orden público comunitario, no sólo los tribunales estatales, sino también los árbitros están obligados a aplicar de oficio el art. 81 TCE.

3..$^{\circ}$ ) Como los tribunales arbitrales no son considerados jurisdicción nacional en el sentido del art. 234 TCE y no puede interponer una cuestión prejudicial (STJCE de 23 de marzo de 1982, Nordsee, C-102/81, Rec., p. 1.095, apartados 10 y 12), existe un interés manifiesto para el orden público comunitario en que los asuntos de orden público comunitario puedan ser examinados por las jurisdicciones nacionales llamadas a pronunciarse sobre la validez de las sentencias arbitrales y puedan ser objeto eventualmente de un reenvío prejudicial ante el Tribunal.

Así, pues, cabe invocar por vez primera esta cuestión ante los tribunales nacionales, aunque anteriormente no se haya debatido esta cuestión de orden público comunitario en el transcurso del procedimiento arbitral.

46. b) El Derecho holandés no permitía la anulación del plazo arbitral más que en un plazo muy breve: tres meses después del depósito de la sentencia arbitral en la jurisdicción competente. Esta regla procesal impedía, en el caso concreto, el recurso contra una sentencia arbitral contraria al orden público comunitario. ¿Es incompatible tal normativa procesal estatal con el Derecho comunitario? Para el Tribunal de Justicia estuvo claro que no era así puesto que:

1. $\left.{ }^{\circ}\right)$ El plazo no era demasiado breve si se compara con los fijados en los ordenamientos jurídicos de otros Estados miembros ni 
vuelve demasiado difícil o prácticamente imposible el ejercicio de los derechos conferidos por el orden jurídico comunitario.

$\left.2 .^{\circ}\right)$ Los principios de seguridad jurídica y de respeto a la cosa juzgada justifican que, fuera de los plazos legales, no se pueda recurrir ni las sentencias de fondo ni las sentencias posteriores que revisten el carácter de sentencias finales parciales: ni siquiera cuando el plazo ha transcurrido para la primera de ellas (la que establece el deber de indemnizar) y aún no ha expirado para la segunda (la que cuantifica la obligación indemnizatoria).

47. Las enseñanzas que derivan de esta sentencia son varias: los árbitros deben controlar de oficio la conformidad con el Derecho europeo de la competencia, dicha conformidad debe poder verificarse en el control ex-post jurisdiccional, los cauces procesales que no impiden o dificultan este control deben ser respetados. Alguna autora (C. PRIETO) ha observado finalmente el propósito del Tribunal de Justicia de no fomentar los actos procesales de mala fe: en este caso, Benetton había procedido, primero, a una resolución injustificada del contrato y, segundo, había intentado un recurso, acusando a sus licenciatarios de una falta (el reparto de mercados) que Benetton conocía años antes y que, hasta el momento de interponer el recurso, no pareció importarle.

48. Por último, cabe preguntarse si el árbitro deja de estar obligado a aplicar de oficio el Derecho de la competencia cuando actúa en un arbitraje de equidad (ex aequo et bono). La respuesta es claramente negativa: En el arbitraje comercial internacional, el árbitro, aun actuando como amigable componedor, no puede prescindir de las reglas que se considera que son de orden público internacional ${ }^{90}$.

\section{Cuestiones procedimentales}

\section{A) Recurso prejudicial}

49. El art. 234 TCE dispone que los órganos jurisdiccionales pueden - o deben, según los casos - plantear una cuestión prejudicial ante el TJCE ${ }^{91}$. Técnicamente la cuestión prejudicial no es otra cosa que un

90 Vid., ad ex., W. ABdelgawad, Arbitrage et droit de la concurrence..., pp. 294-298; B. HANOTIAU, L'arbitrabilité, pp. 139-140; J.-B. RACINE, L'arbitrage commercial international..., pp. 251-255.

91 Vid. Tribunal de Justicia, «Nota informativa sobre el planteamiento de cuestiones prejudiciales por los órganos jurisdiccionales nacionales», DOUE C 143 de 11 de junio de 2005. 
mecanismo interpretativo del Derecho comunitario que pretende asegurar su eficacia y uniformidad, evitando que los tribunales nacionales puedan tener la última palabra en cuestiones hermenéuticas y consolidar así interpretaciones divergentes de una misma regla jurídica. Con este fin, se instituyó una competencia exclusiva en favor del Tribunal de Justicia ${ }^{92}$.

50. Ahora bien, dado que el árbitro puede e, incluso, debe tener que aplicar el Derecho comunitario, cabe preguntarse si puede considerársele una jurisdicción de un Estado miembro y si, por consiguiente, puede plantear una cuestión prejudicial ante el TJCE ${ }^{93}$.

51. La anterior pregunta no es estéril. En primer lugar, porque plantea un dilema; es decir, una cuestión susceptible de varias respuestas. Se puede, en efecto, negar la posibilidad de que el árbitro recurra a la

92 Vid., ad ex., J. BAQUERo CRUZ, «De la cuestión prejudicial a la casación europea: reflexiones sobre la eficacia y la uniformidad del Derecho de la Unión», Revista Española de Derecho Europeo, n. ${ }^{\circ}$ 13, enero-marzo 2005, pp. 35-60; A. BARAV, «Le renvoi préjudiciel communautaire», Justices 1997, n. ${ }^{\circ}$ 6, pp. 1 ss.; S. BARONA VILAR, «La cuestión prejudicial comunitaria», La Ley: Unión Europea, n. ${ }^{\circ}$ 4.333, julio 1997, pp. 2-9; M.-C. BERGERES, «Vademecum de la question préjudicielle de l'article 177 du Traité CEE», D. 1994, chron. 181; M. Cienfuegos Mateo, «La apreciación de la necesidad de plantear una cuestión prejudicial ex artículo 177 del Tratado CE en la jurisprudencia española», Not.UE, n. ${ }^{\circ}$ 163-164, agosto-septiembre 1998, pp. 9-24; M. DARMON, «Réflexions sur le recours préjudiciel», Cah.dr.eur., 1995, pp. 577 ss.; M. ${ }^{a}$ FRAILE ORTIZ, «Negativa del juez nacional a plantear una cuestión prejudicial ante el Tribunal de Justicia de las Comunidades Europeas», Revista Española de Derecho Europeo, n. ${ }^{\circ}$ 7, julio-septiembre 2003, pp. 433-466; M. JiMENo Bulnes, La cuestión prejudicial del art. 177 TCE, Barcelona, 1996; M. LAMELA FERnáNDEZ, «Cuestión prejudicial», Not.C.E.E., n. ${ }^{\circ}$ 66, julio 1990, pp. 137-140; C.-O. LENZ, «Rôle et fonctionnement de la procédure de décision préjudicielle en droit communautaire», JCP 1995.I.3834; R. LEÓN JIMÉNEZ, «Procedimiento y aspectos formales de la cuestión prejudicial presentada ante el Tribunal de Justicia de las Comunidades Europeas», Not.UE, n. ${ }^{\circ}$ 221, junio 2003, pp. 59-64; J. MorCILlo MoreNo, «La cuestión prejudicial comunitaria: la obligación de remisión prejudicial», Not.UE, n. ${ }^{\circ}$ 201, octubre 2001, pp. 9-28; M. PASTOR LÓPEZ, «La obligatoriedad o el carácter facultativo de la cuestión prejudicial del Derecho comunitario europeo», Not.C.E.E., n. ${ }^{\circ} 25$, febrero 1987, pp. 103-113; J. PERTEK, La pratique du renvoi préjudiciel en droit communautaire. Coopération entre CJCE et juges nationaux, Paris, 2001; M. REVEnga SÁNCHEZ, «Algunos aspectos problemáticos en la regulación de la cuestión prejudicial (art. 177 TCEE)», Not.UE, n. ${ }^{\circ} 121$, febrero 1995, pp. 37-45; M. ${ }^{a} I$. ROFES I PUJOL, «La cuestión prejudicial ante el Tribunal de Justicia: una vía privilegiada de diálogo entre jurisdicciones», en CGPJ/Gobierno Vasco, Ordenamiento jurídico comunitario y mecanismos de tutela judicial efectiva, Madrid, Vitoria, 1995, pp. 153-172; G. RouHETTE, «Quelques aspects de l'application du mécanisme du renvoi prejudiciel», Justices, 1997, n. ${ }^{\circ}$ 6, pp. 15 ss.; M. VILlagóMEZ CeBrián, La cuestión prejudicial en el Derecho comunitario europeo: artículo 177 del Tratado de la Comunidad Europea, Madrid, 1994.

93 Vid., ad ex., W. AbDelgawad, Arbitrage et droit de la concurrence..., pp. 316-331; B. HANOTIAU, L'arbitrabilité, pp. 140-144. 
cuestión prejudicial, señalando que el art. 234 TCE no contempla el arbitraje. Pero también se puede esgrimir que la técnica del arbitraje, como medio de arreglo de diferencias, deriva de la ley nacional, ya que las leyes de los Estados miembros contemplan esta posibilidad, que los árbitros gozan de poderes muy semejantes a los de los jueces y que, por tanto, serían jurisdicciones nacionales. En segundo lugar, porque, cualquiera que sea la respuesta, ésta tiene importantes consecuencias prácticas.

52. En el debate doctrinal y jurisprudencial que dicha cuestión originó, ciertas ideas se fueron afianzando y ganando terreno:

1. a) Que una cosa es que el ordenamiento jurídico contemple la posibilidad del arbitraje y otra que lo imponga. Cuando efectivamente tiene lugar un arbitraje, éste no tiene su origen inmediato en la ley, sino en la voluntad de las partes que deciden recurrir a él. Ergo: El órgano arbitral —que no administra justicia en nombre del Estado, sino de las partes que lo eligenno es equiparable a un órgano judicial de un Estado miembro.

2. $\left.{ }^{a}\right)$ Que, como señaló la STJCE de 30 de junio de 1966, Vaassen/Direction du Baembtendfonds voor het mejnbedrijf, 61/65, Rec., p. 378, una jurisdicción es un organismo que ha sido instituido para juzgar de manera permanente y cuya competencia se impone a los justiciables. Dicho con otros términos, un órgano jurisdiccional tiene un origen legal, es un órgano permanente, su jurisdicción tiene carácter obligatorio y aplica el Derecho mediante un procedimiento sometido a varios principios procesales, en especial el principio contradictorio. Ergo faltaban tres caracteres esenciales: El órgano arbitral, que no es permanente, que no administra justicia en nombre del Estado y cuya existencia y funcionamiento depende de la voluntad de los particulares que optan por él, no puede ser una jurisdicción arbitral.

3. a) Que, como confirmación y no como excepción a la anterior idea, la STJCE de 30 de junio de 1966, Vaassen/Direction du Baembtendfonds voor het mejnbedrijf, 61/65, Rec., p. 378, que contemplaba un caso en el que intervenía un tribunal de arbitraje de la caja de los empleados de las minas de Holanda, apuntó que un arbitraje obligatorio no es más que una jurisdicción excepcional a la que un legislador nacional ha querido otorgar el régimen jurídico del arbitraje.

53. Hubo que esperar, sin embargo, a comienzos de los años 80 , para que este mismo Tribunal resolviese considerar que los árbitros no 
pueden calificarse de jurisdicción de un Estado miembro con el fin de beneficiarse del art. 234 TCE y poder, así, preguntarle la interpretación del Derecho comunitario (STJCE de 23 de marzo de 1982, Nordsee, C-102/81, Rec., p. 1095) ${ }^{94}$. En este caso, en el que el fondo debía ser regulado por la ley alemana, el Tribunal de Justicia se consideró incompetente para responder a las cuestiones planteadas por el órgano arbitral. Según el Tribunal de Justicia la semejanza de actividad del tribunal arbitral con la actividad jurisprudencial no era suficiente para conferir al árbitro de una jurisdicción de un Estado miembro en el sentido del art. 234 TCE. En general, la doctrina acogió mal esta decisión, a la que algún autor (H.G. GHARAVI) calificó como «sin sentido y peligrosa» (senseless and dangerous) ${ }^{95}$.

54. Posteriormente, el Tribunal de Justicia ha confirmado la jurisprudencia según la cual los árbitros no son órganos jurisdiccionales, a los efectos de poder plantear cuestiones prejudiciales (STJCE de 27 de enero de 2005, Denuit, C-125/04 ${ }^{96}$. El TJCE se ha referido a los mismos argumentos ya vertidos en el asunto Nordsee para no pronunciarse sobre las cuestiones planteadas por el Colegio arbitral de la Comisión de Litigios sobre Viajes de Bélgica con este tenor: «Dado que, en el asunto principal, las partes contratantes no están obligadas, de hecho o derecho, a dirimir sus diferencias a través del arbitraje y que las autoridades públicas belgas no están implicadas en la elección de la vía arbitral, el collège d'arbitrage de la Comisión de Litiges Voyages no puede ser considerado un órgano jurisdiccional de un Estado miembro en el sentido del art. $234 \mathrm{CE})^{97}$.

94 Vid. STJCE de 23 de marzo de 1982, Nordsee, C-102/81, Rec., p. 1095, apartado 13.

95 H.G. Gharavi, «EC Competition Law and the Proper Scope of Arbitration», Arbitration, 63, 1987, pp. 59-66, concr. p. 63; A. MC ClELLAN, Le rôle de l'arbitrage commercial..., pp. 301-314, concr. pp. 308-309; X. DE MELLO, «Arbitrage et droit communautaire», Rev. arb., 1982, pp. 349 ss.; C.M. SснміттноғF, «Arbitration and EEC Law», C.M.L.Rev., 24, 1987, pp. 143-157, concr. p. 153-157; A. RigOZZI, Arbitrage, ordre public..., pp. 455-487, concr. p. 471. A favor, de la postura adoptada por el TJCE, P.L. HETSCH, L'arbitrage en droit..., pp. 46-58, concr. 50 ss.

96 Vid. STJCE de 27 de enero de 2005, Denuit, C-125/04.

97 Vid. STJCE de 27 de enero de 2005, Denuit, C-125/04, apartado 16. El litigio surge con ocasión de un contrato celebrado entre una agencia de viajes y dos clientes. Según el contrato estos últimos realizarían un viaje a Egipto por 2.765 euros. El precio incluía el transporte por avión desde Bruselas — también el viaje de vuelta- y un crucero por el Nilo durante 7 días. En las condiciones particulares del contrato se daba la posibilidad de revisar los precios pagados si el tipo de cambio hubiera cambiado un $10 \%$ en el momento de la salida del viaje. Los consumidores, el Sr. Denuit y la Sra. Cordenier exigieron a la agencia que les reembolsara 217,61 euros, ya que se había producido una apreciación del euro - en el momento de la firma del contrato un euro costaba 0,91 dólares y en el mo- 
55. Ahora bien, una cosa es que los tribunales arbitrales no sean propiamente jurisdicciones, de origen legal y permanente, de los Estados miembros de la UE susceptibles de beneficiarse del mecanismo procedimental e interpretativo del art. 234 TCE y otra, sin embargo, que los tribunales estatales encargados de controlar los laudos arbitrales, en sede de revisión o de reconocimiento o ejecución, sí podrían plantear una cuestión prejudicial ante el TJCE acerca del Derecho europeo de la competencia aplicado por el árbitro (PH. Fouchard, C. GAVALDA/G. PARLÉANI) ${ }^{98}$. Es ésta, en todo caso, una exégesis que, actualmente, requeriría una interpretación evolutiva de la jurisprudencia comunitaria; ya que ésta reconoce, hoy por hoy, exclusivamente legitimación para interponer el recurso prejudicial a los órganos judiciales de los Estados miembros que deben resolver el fondo del asunto y que, con dicho propósito, requieren la interpretación del Derecho comunitario por el Tribunal de Justicia ${ }^{99}$.

56. No sólo esto, sino que, de lege ferenda, algunos autores sostienen que el árbitro debería poder plantear cuestiones prejudiciales ante

mento de la salida costaba 1,08- La agencia se negó a la devolución acogiéndose a la Ley belga de transposición de la Directiva 90/314/CEE del Consejo, de 13 de junio de 1990, relativa a los viajes combinados, las vacaciones combinadas y los circuitos combinados (DO L 158, p. 59), cuyo artículo 11, apartado 1 dispone: «El precio convenido en el contrato no podrá ser revisado, salvo si el contrato establece de manera explícita la posibilidad de revisión al igual que su método exacto de cálculo y siempre que la revisión sea consecuencia de variaciones: a) de los tipos de cambio aplicados al viaje, y/o; b) del coste de los transportes, incluido el coste del carburante, y/o; c) de las tasas e impuestos relativos a determinados servicios. En tal caso, es necesario que las mencionadas variaciones den lugar igualmente a una reducción del precio». El mencionado artículo 11 apartado 1 de la Ley Belga es la transposición del artículo 4 apartado 4 de la Directiva 90/314/CEE, precepto este último que dispone lo siguiente: «Los precios establecidos por el contrato no podrán ser revisados, salvo si éste establece de manera explícita la posibilidad de revisión tanto al alza como a la baja y define las modalidades precisas de cálculo, y si se revisan únicamente para tener en cuenta variaciones: del coste de los transportes, incluido el coste del carburante; de las tasas e impuestos relativos a determinados servicios, como los impuestos de aterrizaje, de desembarco o de embarque en puertos y aeropuertos; de los tipos de cambios aplicados al viaje organizado de que se trate». Ante la respuesta negativa dada por la agencia, los demandantes acudieron al collège d'arbitrage de la Comisión de Litiges Voyages para denunciar los hechos. El órgano arbitral consideró que debía plantear al Tribunal de Justicia algunas cuestiones prejudiciales acerca de la interpretación que debía darse al artículo 4, apartado 4, de la Directiva 90/314/CEE.

98 Vid. STJCE de 23 de marzo de 1982, Nordsee, C-102/81, Rec. 1982, p. 1095, apartados 14 y 15. Vid., ad ex., en este sentido, Ph. Fouchard, en Rev. arb., 1982, p. 491; C. GAVALDA/G. PARLÉANI, Droit communautaire des affaires, Paris, 1988, pp. 117 y 687.

99 Vid., ad ex., STJCE de 21 de abril de 1988, Pardini/Ministero del Commercio con l'Estero, 338/85, Rec., p. 2041. 
el TJCE, ya que, si admitimos que los árbitros pueden aplicar el art. 81 TCE en su totalidad, deberíamos en coherencia permitir que estos órganos pudieran preguntar al Tribunal de Justicia acerca de la interpretación del Derecho de la competencia europeo; porque, de otro modo, los laudos arbitrales podrían aportar una interpretación disconforme de las normas europeas de competencia, sin posibilidad de recurso alguno, a menos que se observara un atentado contra el orden público internacional. Es éste un deseo largamente sentido por los medios profesionales cercanos al arbitraje, no sólo con relación al Derecho de la competencia, sino, en general, de todo el ordenamiento jurídico comunitario ${ }^{100}$.

Existiría la posibilidad de que, en el futuro, sin necesidad de reformar el Tratado, se considerase - como sugirió X. DE Mello- que el art. 234 del Tratado de Roma, al disponer que el Tribunal de Justicia será competente para pronunciarse, con carácter prejudicial, «cuando se plantee una cuestión... ante un órgano jurisdiccional de uno de los Estados miembros..., si estima necesaria una decisión al respecto para emitir su fallo» (art. $234 \mathrm{TCE}$, penúltimo apartado) o «cuando se plantee una cuestión de este tipo en un asunto pendiente ante un órgano jurisdiccional, cuyas decisiones no son susceptibles de ulterior recurso judicial de Derecho interno..» (art. $234 \mathrm{TCE}$, in fine), no hace otra cosa que limitarse a regular dos supuestos específicos, cuyo común denominador es el de suscitarse la necesidad de que el Derecho comunitario sea interpretado por el Tribunal de Justicia en litigios que se solventan por órganos judiciales de Estados miembros. Pero fuera de estos dos supuestos, cabría imaginar esa misma necesidad interpretativa en otros tipos de procedimientos, entre los que los arbitrales ocuparían una posición destacada ${ }^{101}$.

Además, por otro lado, la cooperación entre los órganos comunitarios y los árbitros debería ser recíproca y, si admitimos que la Comisión pueda intervenir en el procedimiento arbitral presentando observaciones escritas o verbales — tal como se analizará más adelante-, deberíamos permitir, también, que los árbitros puedan beneficiarse del recurso prejudicial ante el $\mathrm{TJCE}^{102}$.

57. En todo caso, al margen de una eventual reforma del Tratado de Roma, cabría preguntarse si no hay alguna otra vía que posibilite ya

100 Vid., en este sentido, la aspiración manifestada en el segundo Congreso internacional de arbitraje (Rev. arb., 1966, n. ${ }^{\circ}$ spécial, p. 62; X. DE MELLO, «Arbitrage et droit communautaire», Rev. arb., 1982, pp. 349 ss., concr. p. 384).

101 X. DE MELlo, «Arbitrage et droit communautaire», Rev. arb., 1982, pp. 349-403, concr. p. 398.

102 Vid. W. AbDELGAWAD, «L'arbitrage international et le nouveau Règlement...», Rev. arb., n. ${ }^{\circ} 2,2004$, p. 275. 
la cooperación entre los órganos arbitrales y las instituciones comunitarias. Hay dos buenas razones para ello. Primera: Como veremos, el control de los laudos arbitrales por los tribunales estatales en caso de recurso de anulación o de exequatur es muy limitado y no supone una revisión del fondo. Segunda: La Comisión carece de un mecanismo general que le permita reaccionar jurídicamente frente a los laudos arbitrales que, de forma injustificada, ignoran el Derecho comunitario de la competencia ${ }^{103}$. Por esto, N. SPIEGEL ha propugnado la implantación del principio «cooperación en lugar de control» (Prinzip «Kooperation statt Kontrolle» $)^{104}$. En aras de este principio, debieran explorarse las posibilidades procedimentales que brinda el Reglamento 1/2003.

58. Así, los árbitros podrían utilizar el mecanismo de cooperación previsto en el art. 15.1 del Reglamento 1/2003 para los órganos jurisdiccionales. Este precepto posibilita que los juzgados y tribunales nacionales puedan solicitar a la Comisión información o dictámenes que tenga en su poder sobre la aplicación de las normas de competencia. De este modo, se favorece una interpretación uniforme del Derecho europeo de la competencia por parte de los órganos jurisdiccionales. Con este objetivo de conseguir que las normas de competencia sean aplicadas de forma homogénea por cualquier instancia competente, y teniendo en cuenta que los árbitros no pueden acudir al TJCE, parece razonable que esta vía de cooperación entre los órganos jurisdiccionales y la Comisión pueda ser utilizada en relación con los árbitros ${ }^{105}$.

59. Por otra parte, el art. 15.3 del Reglamento $1 / 2003$ posibilita que la Comisión - además de las autoridades de competencia- pueda presentar observaciones escritas a los órganos jurisdiccionales sobre cuestiones relativas a los arts. 81 y 82 TCE. También podrán realizar observaciones orales siempre que lo permita el órgano jurisdiccional correspondiente. En ambos casos, la intervención de la Comisión queda justificada para aportar una aplicación coherente de los arts. 81 y 82 TCE.

La regulación del art. 15.3 R 1/2003 tiene, como destinatarios, a los órganos jurisdiccionales de los Estados miembros. Cabría preguntarse si esta previsión podría aplicarse también en relación a los árbitros. En un primer momento, la confidencialidad del arbitraje, así como la independencia de los árbitros, podrían ser razones esgrimidas para negar esta posibilidad ${ }^{106}$.

103 Vid. J.-B. Racine, L'arbitrage commercial international..., pp. 516-517.

104 N. SPIEGEL, Kartellprivatrecht..., pp. 269-271.

105 Ibidem, pp. 266-268.

106 Ibidem, p. 268. 
Sin embargo, también podría argumentarse en sentido contrario y, así, considerar que cabría que el art. 15.3 R1/2003 se aplicara en relación con los árbitros. Para ello, debería exigirse ciertos condicionamientos ${ }^{107}$ :

1. $\left.{ }^{\circ}\right)$ Las intervenciones de la Comisión, presentando observaciones, bien sea escritas, bien sea de forma verbal, deberían ser autorizadas por el órgano arbitral ${ }^{108}$

2. $\left.{ }^{\circ}\right)$ Una vez autorizada la intervención de la Comisión, el árbitro debería comunicárselo a las partes y darles la posibilidad de responder y defenderse, si es el caso.

3..$\left.^{\circ}\right)$ Como expresamente señala el art. $15.3 \mathrm{R} 1 / 2003$, las observaciones que realice la Comisión tendrán por objetivo promover una aplicación coherente de los arts. 81 y 82 TCE. Su intervención, por tanto, además de ser excepcional — cuando haya interés público comunitario- sólo está encaminada a clarificar la interpretación que se ha de dar de estos artículos, y no a aportar una concreta solución del caso. Las observaciones de la Comisión, en este sentido, sólo deben ayudar al árbitro a resolver el caso.

4. $\left.{ }^{\circ}\right)$ La Comisión podrá pedir a los órganos jurisdiccionales - también a los árbitros - información del asunto para poder hacer una mejor valoración del caso y presentar así unas observaciones más ajustadas (art. 15.3). La transmisión de esta información podría conculcar el principio de confidencialidad del arbitraje, sin embargo, el art. 28 R1/2003 garantiza que la Comisión no divulgará dicha información y que respetará el secreto profesional.

\section{B) Procedimiento comunitario y procedimiento arbitral}

60. En todo caso, cabe cuestionarse si sobre los árbitros recaería la obligación de suspender el procedimiento arbitral, hasta que la Comisión, iniciado un procedimiento, resuelva sobre la eventual inobservancia de los arts. 81 u 82 TCE: el árbitro — se considera - tiene «no solamente la posibilidad de suspender el procedimiento, sino también la de proseguir si estima que la violación es inexistente o, por el contrario, manifiesta» ${ }^{109}$.

107 Ibidem, pp. 268-271.

108 La autorización de las partes en el proceso arbitral no debería exigirse puesto que podría suponer que la Comisión no pudiera intervenir y, por tanto, que no se aplicara correctamente el Derecho europeo de la competencia por el interés de alguna de las partes.

109 Vid. B. HANOTIAU, «L'arbitrage et le droit européen de la concurrence», en R. BRINER/Y. Derains [et al.], L'arbitrage et le Droit Européen, Bruylant, Bruxelles, 1997, p. 55. También W. ABDElgaWAD, Arbitrage et droit de la concurrence..., pp. 308-314. 
61. En virtud del art. 16 del Reglamento 1/2003, los órganos jurisdiccionales y las autoridades de competencia no podrán adoptar resoluciones incompatibles con una Decisión dictada por la Comisión sobre el acuerdo, decisión o práctica concertada en liza. Así mismo, los órganos jurisdiccionales deberán evitar dictar una resolución que pueda entrar en conflicto con una previsible Decisión que vaya a dictar la Comisión en un procedimiento que ya haya sido incoado —el órgano jurisdiccional tiene la facultad de suspender su procedimiento en espera de que la Comisión emita su Decisión y también puede plantear una cuestión prejudicial según el art. 234 TCE-.

Esta forma de cooperación entre los órganos jurisdiccionales y las autoridades nacionales de competencia en relación con la Comisión podría extenderse y hacerse aplicable también respecto de los árbitros. Los árbitros no se encuentran vinculados por este deber de tener en cuenta las Decisiones de la Comisión, por tanto, podrían dictar un laudo arbitral que fuera contradictorio con lo recogido en una Decisión de la Comisión. Sin embargo, dicho laudo podría ser objeto de nulidad ante un órgano jurisdiccional de un Estado miembro, precisamente por esa infracción del Derecho comunitario. Por tanto, si bien, no por obligación, sí por conveniencia, los árbitros deberían tener en cuenta las Decisiones dictadas - o pendientes de ser dictadas - por la Comisión a la hora de emitir sus laudos arbitrales ${ }^{110}$.

Las partes pueden querer someter a arbitraje las disputas que puedan surgir de un acuerdo realizado entre ellas, acuerdo claramente incompatible con el Derecho de la competencia por recoger una fijación de precios en el mercado, ad ex., con la finalidad de que el acuerdo pueda ponerse en práctica y no se le apliquen las normas de competencia. En este caso, pueden recoger como una cláusula más en el acuerdo la sumisión al arbitraje. Pues bien, ante esta situación, una de las empresas implicadas podría poner en conocimiento de la Comisión la existencia de ese acuerdo anticoncurrencial, con la cláusula de sumi-

110 Vid. A. P. Komninos, «Arbitration and the Modernisation of European Competition Law Enforcement», World Compet., 24 (2), 2001, p. 232; R. NAZZINI, «International Arbitration and Public Enforcement of Competition Law», Eur.Compet.L.Rev., n. ${ }^{\circ}$, 2004, pp. 161-162.

Algún autor considera que los árbitros no deberían suspender el procedimiento en espera de que la Comisión dicte la Decisión. El arbitraje se caracteriza por la celeridad, y esta razón es la que justifica que no sea conveniente suspender el procedimiento arbitral. Sin embargo, cuando haya un riesgo cierto de contradicción entre el laudo arbitral y la Decisión de la Comisión, en ese caso, por razones de seguridad jurídica, el árbitro debería suspender el procedimiento hasta que la Comisión adopte su Decisión (W. AbDELGaWAD, L'arbitrage international et le nouveau Règlement..., pp. 273-274. 
sión al arbitraje incluida. En este supuesto, la cláusula arbitral podría ser prohibida por la Comisión en virtud al art. 81.2 TCE por contribuir a que la aplicación de las reglas de competencia sea eludida ${ }^{111}$.

62. Los árbitros, al igual que los órganos jurisdiccionales, tienen la opción de suspender el procedimiento seguido ante ellos, hasta el momento en que la Comisión emita la Decisión en conflicto. Ahora bien, por el principio de celeridad del proceso arbitral, la suspensión del mismo sólo debe adoptarse cuando la contrariedad entre el laudo y la decisión - de la Comisión o de la autoridad nacional de competencia- sea real y no meramente hipotética. Por tanto, los árbitros no deberían suspender el proceso por el solo hecho de que pudiera iniciarse una investigación administrativa ${ }^{112}$.

63. Los dos principios que deben inspirar el arbitraje son, además del ya estudiado de la eficacia del laudo arbitral, la autonomía de la voluntad de las partes ${ }^{113}$. En efecto, las partes que han elegido el arbitraje como modo de resolución de sus disputas son las que gobiernan dicho arbitraje. El poder de los árbitros en el arbitraje se lo otorgan las partes que los han elegido. Por tanto, la decisión de suspender o no el procedimiento arbitral la deberían tomar los árbitros teniendo en cuenta la opinión de las partes. Sólo en el caso de que éstas no se pongan de acuerdo, los árbitros podrían decidir de forma unilateral dicha suspensión ${ }^{114}$.

\section{C) Comunicación de las sentencias arbitrales a la Comisión}

64. Los Estados miembros tienen la obligación de remitir a la Comisión una copia de las sentencias dictadas por sus órganos jurisdiccionales, en las que se hayan aplicado los arts. $81 \mathrm{u} 82$ TCE (art. 15.2 R 1/2003). El Reglamento 1/2003 dispone que la remisión de la copia de las sentencias debe realizarse después de que éstas hayan sido notificadas a las partes. Ante esta obligación de remisión de sentencias, cabría preguntarse si los árbitros, por analogía, del mismo modo que pueden aplicar los arts. 81 y 82 TCE, deberían someterse, también, a las mismas obligaciones que deben observarse respecto de los órganos jurisdiccionales, y, por tanto, si estarían obligados a remitir a la Comisión una copia de los laudos arbitrales en los que hubieran aplicado los arts. $81 \mathrm{u} 82 \mathrm{TCE}$.

111 Vid. Dec. Com. 3 junio 1975, Haarden-en Karchelhandel, JO n. ${ }^{\circ}$ L 159, 21 junio 1975.

112 Vid. R. NAZZINI, International Arbitration and Public Enforcement..., p. 158.

113 Ibidem.

114 Ibidem, p. 159. 
65. Si bien es razonable preguntarse si los árbitros deberían quedar sometidos a la misma disciplina que los tribunales nacionales, respecto de esta obligación de los Estados miembros de remitir una copia de las sentencias dictadas sobre la aplicación del art. 81 u 82 TCE, podría considerarse que es una cuestión de menor importancia ${ }^{115}$.

En efecto, el objetivo de la imposición de este deber no es otro que informar a la Comisión. Por tanto, llegado el caso, con esta obligación no se evitarían aplicaciones incorrectas del Derecho de la competencia por parte de los jueces nacionales. Con este panorama, teniendo en cuenta, además, la naturaleza privada y confidencial de los arbitrajes, no se considera relevante cuestionarse sobre si los laudos arbitrales - documentos no públicos- deben ser remitidos a la Comisión cuando los árbitros hayan aplicado los arts. 81 u 82 TCE ${ }^{116}$.

66. En el sentido contrario del canal de comunicación, los árbitros tienen dos vías - podría plantearse como una alternativa - para obtener información que posee la Comisión:

1. $\left.{ }^{\circ}\right)$ A través de una comunicación directa entre el órgano arbitral y la Comisión, con el acuerdo de las partes en el proceso y, si no lo hay, por iniciativa unilateral del árbitro si lo considera relevante y siempre que se respeten los principios de transparencia e igualdad entre las partes ${ }^{117}$;

2. $\left.{ }^{\circ}\right)$ Mediante la solicitud del árbitro a cualquiera de las partes respecto de documentos que éstas hayan remitido a la Comisión, siempre respetando, eso sí, la confidencialidad y el secreto profesional ${ }^{118}$.

\section{D) Recurso en caso de inaplicación del Derecho de la competencia}

67. Los laudos arbitrales pueden ser objeto de control por parte de los órganos jurisdiccionales nacionales ${ }^{119}$. Este control debe quedar li-

115 Según algún autor, la remisión de los laudos arbitrales a la Comisión es inconcebible, a menos así lo acepten las partes implicadas en el proceso arbitral (vid. L. IDOT, «Arbitration and the Reform of Regulation 17/62», en C.-D. Ehlermann/I. AtANASIU (eds.), European Competition Law Annual: 2001, Effective Private Enforcement of EC Antitrust Law, Hart Publishing, Oxford, 2003, p. 318).

116 Vid. A. P. Komninos, «Arbitration and the Modernisation of European Competition Law Enforcement», World Compet., 24 (2), 2001, p. 226.

117 Vid. R. NAZZINI, International Arbitration and Public Enforcement..., p. 162.

118 Ibidem, p. 159.

119 W. AbDElgawad, Arbitrage et droit de la concurrence..., pp. 425-494; J.-B. RaCine, L'arbitrage commercial international..., pp. 513-516; N. SPIEGEL, Kartellprivatrecht..., pp. 146-196. 
mitado a la nulidad del laudo ${ }^{120}$ y a su reconocimiento y ejecución ${ }^{121}$. Ante cualquiera de estas peticiones, el juez nacional deberá analizar si el laudo arbitral atenta contra el orden público de ese Estado. El TJCE ha considerado que el art. 81 TCE es orden público de los Estados miembros de la UE: «No obstante, con arreglo al art. 3, letra g) del Tratado CE [actualmente, art. 3 CE, apartado 1, letra g)], el art. 85 del Tratado constituye una disposición fundamental indispensable para el cumplimiento de las misiones confiadas a la Comunidad, especialmente para el funcionamiento del mercado interior. La importancia de dicha disposición hizo que los autores del Tratado establecieran expresamente en el apartado segundo del art. 85 del Tratado, que los acuerdos y decisiones prohibidos por este artículo son nulos de pleno derecho. (...) En efecto, por los motivos mencionados en el apartado 36 de la presente sentencia, el art. 85 del Tratado puede considerarse una disposición de orden público en el sentido de dicho Convenio» ${ }^{122}$.

\section{E) Retirada del beneficio de una exención por categorías}

68. La Comisión puede retirar individualmente el beneficio de un Reglamento de exención por categorías cuando estime, en el caso concreto, que la aplicación de dicho Reglamento provoca efectos incompatibles con el art. 81.3 TCE (art. 29.1 R 1/2003).

La autoridad nacional de competencia, por su parte, también puede retirar el beneficio de una exención por categorías cuando entienda que la aplicación del Reglamento de exención produzca efectos incompatibles con el art. 81.3 TCE en el territorio de un Estado miembro o en una parte de dicho territorio que represente un mercado geográfico distinto (art. $29.2 \mathrm{R} \mathrm{1/2003).}$

69. Los árbitros, al igual que los órganos jurisdiccionales, no tienen esta posibilidad de retirada individualizada de exenciones. Por tanto, no podrían, llegado el caso, realizar una retirada formal de la aplicación de un Reglamento de exención por categorías. Ahora bien, lo que sí podrían hacer es declarar incompatible con el Derecho de la competencia una entente en la que no concurren los presupuestos del art. 81.3 TCE. Por lo tanto, aunque la consecuencia final sea la misma, la vía seguida, sin embargo, es diferente y resulta respetuosa con la nueva regulación ${ }^{123}$.

120 Vid., ad ex., B. HANOTIAU, L'arbitrabilité, pp. 147-149.

121 Vid. STJCE 1 junio 1999, Eco Swiss, C-126/97, Rec. 1999, p. I-3055, apartado 35.

122 STJCE 1 junio 1999, Eco Swiss, C-126/97, Rec. 1999, p. I-3055, apartados 36 y 39.

123 Vid. W. Abdelgawad, Arbitrage et droit de la concurrence..., pp. 215 y 218-221; ID., L'arbitrage international et le nouveau Règlement..., pp. 263-264. 


\section{Control del laudo arbitral en el exequatur}

70. Los laudos arbitrales se consideran cosa juzgada entre las partes implicadas en los mismos. Sin embargo, no existe ningún órgano en el contexto arbitral que pueda hacer cumplir el contenido de los laudos de forma coactiva. Por tanto, si las partes no cumplen voluntariamente lo acordado, la única posibilidad de exigir el sometimiento a lo dispuesto en el laudo es acudir a un órgano jurisdiccional.

71. La parte interesada en el laudo arbitral puede solicitar la ejecución del mismo ante los jueces y tribunales de un Estado. Los órganos jurisdiccionales nacionales ante los que se pide la ejecución del laudo aplicarán sus normas en la materia para proceder a conceder el exequatur o a denegarlo, según el caso.

El Convenio de Nueva York sobre reconocimiento y ejecución de sentencias arbitrales, de 10 de junio de 1958, está en vigor en más de 100 países. Por su extenso ámbito de aplicación espacial, es la norma a tener en cuenta a la hora de analizar el exequatur de los laudos arbitrales, sobre todo si tenemos en cuenta que los 25 países de la UE son Estados parte del Convenio.

72. El Convenio de Nueva York es aplicable para el reconocimiento y ejecución de laudos arbitrales, con independencia del país del que procedan ${ }^{124}$. Por lo tanto, en principio, la parte interesada podrá acudir a los jueces y tribunales de un Estado parte del Convenio de Nueva York y solicitarles la ejecución del laudo arbitral, sin importar en qué Estado haya sido dictado. Los órganos jurisdiccionales de los Estados contratantes, entonces, tendrán que verificar que no concurre ningún motivo para denegar la ejecución de la sentencia arbitral, comprobado lo cual, declararán ejecutivo el laudo y se podrá proceder a la ejecución efectiva del mismo.

73. Uno de los motivos que recoge el Convenio de Nueva York para no reconocer o ejecutar el laudo arbitral —el más importante a los efectos de este trabajo- es el atentado contra el orden público internacional del foro (art. V.2.b). Las normas de Derecho europeo de la competencia forman parte del orden público de todos los Estados parte de la Unión Europea, por lo que, si se solicita la ejecución de una senten-

124 A menos que algún Estado parte realice una reserva al respecto, y disponga que sus órganos jurisdiccionales sólo van a reconocer y ejecutar sentencias arbitrales que procedan de otro Estado contratante (art. I.3). 
cia arbitral en un Estado europeo, y dicho laudo arbitral no ha respetado las normas comunitarias de competencia, no va a ser ejecutado en dicho Estado por infracción del orden público ${ }^{125}$.

74. No obstante lo dicho anteriormente, algún autor entiende que la excepción de orden público debería alegarse sólo cuando las normas de competencia no observadas en el laudo arbitral sean las correspondientes a un Estado estrechamente vinculado con el caso ${ }^{126}$. De este modo, un órgano jurisdiccional no debería acogerse al no respeto de las normas de competencia del foro para no ejecutar un laudo arbitral, cuando se trata de un Estado - el del foro- alejado de la esfera del supuesto de hecho. Del mismo modo, tampoco debería entender que el árbitro se ha excedido - excepción ultra petita - cuando ha observado normas de competencia no recogidas en la ley elegida por las partes, siempre que dichas normas estén estrechamente conectadas con el caso. Es más, los órganos jurisdiccionales deberían poder rechazar la ejecución de un laudo arbitral cuando el árbitro no ha tenido en cuenta las normas de competencia de un ordenamiento de un tercer Estado conectado con el caso.

75. Al lado de las dos posturas anteriores - la que considera que un motivo para denegar la ejecución de un lado arbitral es el atentado contra el orden público internacional del foro, y la que entiende que sólo debería alegarse el orden público internacional del foro cuando el Estado requerido esté estrechamente vinculado con el caso- encontramos una tercera tesis: por el principio de aplicación uniforme del Derecho europeo de la competencia, cuando el árbitro que ha dictado el laudo esté situado en un Estado de la UE y el juez ante el que se solicita la ejecución de dicho laudo también forma parte del territorio comunitario, la infracción de las normas del Derecho europeo de la competencia por parte del árbitro siempre sería un motivo para no ejecutar la sentencia arbitral en territorio comunitario. El espacio comunitario se convertiría, a estos efectos, en un único foro y, por tanto, los jueces a los que se les pide la ejecución de un laudo arbitral dictado en la Unión Europea deberían poder alegar el orden público para denegar la ejecución, cuando se hayan vulnerado normas del Derecho europeo de la compe-

125 Vid. STJCE de 1 de junio de 1999, Eco Swiss China Time Ltd/Benetton International NV, C-126/97, Rec., p. I-3055, apartados 36-39.

126 Vid. L. G. RADICATI DI BROZOLO, «Antitrust: a paradigm of the relations between mandatory rules and arbitration $-\mathrm{a}$ fresh look at the second look», Intl. Arbitration L. R., 1, 2004, p. 27. 
tencia, aunque dicha infracción no afecte directamente a ese concreto Estado miembro en el que se sitúa el juez competente para el exequatur. Lo importante es que la vulneración de estas normas comunitarias afecte al espacio intracomunitario.

76. Se podría, incluso, ir más allá: Cuando el acuerdo anticompetitivo afecte al mercado intracomunitario, los árbitros competentes para conocer del asunto, aun estando situados fuera de la UE - Suiza, ad ex.deberían aplicar las correspondientes normas del Derecho comunitario de la competencia ${ }^{127}$. El factor relevante para decidir la aplicación del Derecho europeo de la competencia es que el comportamiento anticompetitivo afecte al mercado intracomunitario (Auswirkungsprinzip) ${ }^{128}$, independientemente de que el acuerdo se haya concluido fuera de la UE y por parte de empresas con sedes extracomunitarias ${ }^{129}$.

127 Sentencia CCI n. ${ }^{\circ}$ 8.626/1996, Clunet, 1999, pp. 1.073-1.079, con nota de J.-J. ARNÁLDEZ.

128 Sobre el Auswirkungsprinzip en el arbitraje comercial internacional, vid., ad ex., N. SPIEGEL, Kartellprivatrecht..., pp. 250-255.

129 STJCE de 28 de abril de 1998, Javico/Yves Saint Laurent Parfums, C-306/96, Rec., p. I-01983. 